\title{
Stemming the Tide of Law Student Depression: What Law Schools Need To Learn from the Science of Positive Psychology
}

\author{
Todd David Peterson ${ }^{*}$ and Elizabeth Waters Peterson ${ }^{\dagger}$
}

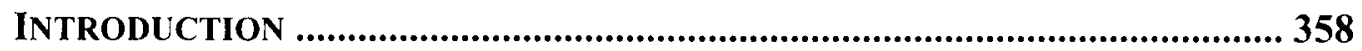

I. THE RESEARCH ON LAW STUDENT DISTRESS ............................................. 365

II. What LaW Schools ARe Doing About LaW StUdent Distress .... 371

III. The CAUSES OF LaW Student DiSTRESS............................................ 375

IV. What the Science of Positive Psychology Can Teach LaW

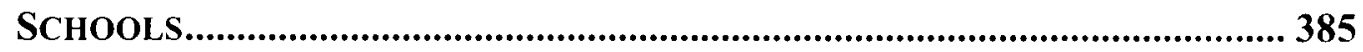

A. What Is Positive Psychology, AND Why Should We CARE? ............. 385

B. Using Positive Psychology To Help Improve LAW Student Well

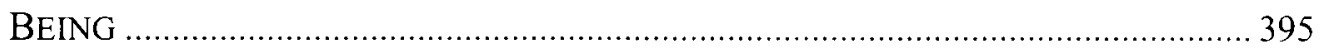

1. LEARNED OPTIMISM AND THE EMOTIONAL PARADOX OF LEGAL

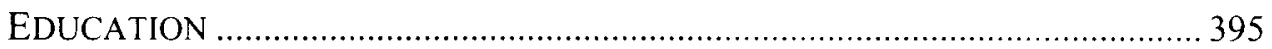

2. THE BROADEN-AND-BUILD THEORY OF POSITIVE EMOTIONS ................. 402

3. THE BENEFITS OF STRENGTHS-BASED EDUCATION................................... 406

4. APPLYING STRENGTHS THEORY TO LEGAL EDUCATION: AN EMPIRICAL

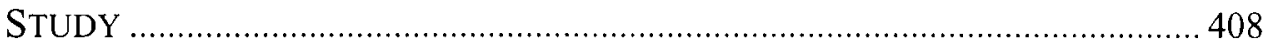

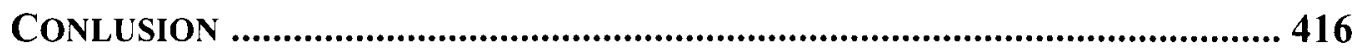

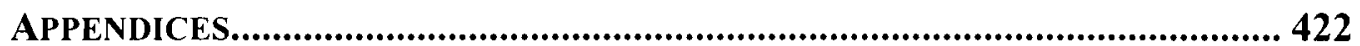

\footnotetext{
* Professor of Law, The George Washington University Law School, B.A. Brown University, 1973, J.D. University of Michigan Law School, 1976.

$\dagger$ B.A. Harvard University, 2005, M.A.P.P., University of Pennsylvania, 2007. The authors appreciatively acknowledge helpful comments and assistance from Shawn Achor, Naomi Cahn, Larry Krieger, Fred Lawrence, Nancy Levit, Christopher Peterson, and Jennifer Waters. The authors are also grateful for expert research assistance from Matthew Albanese and Michael Hissam.
} 


\section{INTRODUCTION}

In a country where the depression rate is ten times higher today than it was in $1960,{ }^{1}$ lawyers sit at the unenviable zenith of depressed professionals. Of all professionals in the United States, lawyers suffer from the highest rate of depression after adjusting for socio-demographic factors, and they are 3.6 times more likely to suffer from major depressive disorder than the rest of the employed population. ${ }^{2}$ Lawyers are also at a greater risk for heart disease, alcoholism and drug use than the general population. ${ }^{3}$ In one sample of practicing lawyers, researchers found that $70 \%$ were likely to develop alcoholrelated problems over the course of their lifetime, compared to just $13.7 \%$ of the general population; of these same lawyers, $20 \%$ to $35 \%$ were "clinically distressed," as opposed to only $2 \%$ of the general population. ${ }^{4}$ With such disproportionate levels of unhappiness, it is not surprising that the profession itself is suffering. Alcoholism or chemical dependency is the cause of the majority of lawyer discipline cases in the United States, ${ }^{5}$ and a growing disaffection with the practice of law pushes 40,000 lawyers to leave the profession every year. ${ }^{6}$

Unfortunately, these problems afflict not only practicing lawyers, but law students as well. While there has been less research on law students than on lawyers, a growing body of literature shows that they too exhibit signs of psychological distress, ${ }^{7}$ including elevated levels of depression, stress, and

1. See Martin E.P. Seligman, Authentic Happiness 117 (2002).

2. See William W. Eaton et al., Occupations and the Prevalence of Major Depressive Disorder, 32 J. OCCUPATIONAL MED. 1079, 1083 (1990).

3. See, e.g., Martin E.P. Seligman, Paul R. Verkuil \& Terry H. Kang, Why Lawlers Are' Unhappy, 10 DEAKIN L. REV. 49, 53 (2005).

4. Connie J.A. Beck, Bruce D. Sales \& G. Andrew H. Benjamin, Lawier Distress: Alcohol-Related Problems and Other Psychological Concerns Among a Sample of Practicing Lawyers, 10 J.L. \& HeAlTH 1, 51 (1995).

5. See, e.g., Rick B. Allan, Alcoholism, Drug Abuse and Lawyers: Are We Ready To Address the Denial?, 31 CreIGHTON L. REV. 265, 268 (1997).

6. Se' Diana Nelson Jones, Legally Unhappy: Experts Horry About Growing Tide of Lawyers Abandoning Careers, Pittsburgh Post-Gazette, May 4. 2005, at E1. For comparison purposes. according to the $\mathrm{ABA}$, there were 1,162,124 active attorneys in the United States at the beginning of 2008. American Bar Association, National Lawyer Population by State (2008), http://www.abanet.org/marketresearch/2008_NATL_LAWYER_by_state.pdf. By way of additional comparison, according to the ABA, the total of J.D.s and LL.B.s awarded for the 20072008 school year was 43.518. American Bar Association. Enrollment and Degrees Awarded, 19632007, http://www.abanet.org/legaled/statistics charts/stats\%20-0 0201 pdf (last visited Apr. 1. 2009).

7. In this paper we use the phrase "psychological distress" as an umbrella term to signify the presence of symptoms related to depression, stress, and anxiety. 
anxiety. ${ }^{8}$ One study found that $44 \%$ of law students meet the criteria for clinically significant levels of psychological distress. ${ }^{9}$ Law students also report significantly higher levels of alcohol and drug use than college and high school graduates of the same age, and their alcohol use increases between their second and third year of law school. ${ }^{10}$ Moreover, these problems seem unique to law students and are not generalizable to other overworked populations of graduate students. For instance, one study showed that compared to medical students in a similarly demanding academic situation, law students have significantly higher levels of stress, stress symptoms, and alcohol abuse. ${ }^{11}$

Contrary to the popular belief that life settles down after the first year of law school, student stress levels appear to increase as the years pass, ${ }^{12}$ and levels of depression and anxiety are still significantly elevated two years after graduation. ${ }^{13}$ We also know that the problems law students suffer are tied directly to the law school experience. Before they enter law school, students show no signs of elevated psychological distress compared to the general population, but just six months into school, their negative symptom levels increase dramatically. ${ }^{14}$ The research seems to suggest that law school is to blame for the alarmingly elevated levels of student distress. ${ }^{15}$

8. See, e.g., G. Andrew H. Benjamin et al., The Role of Legal Education in Producing Psychological Distress Among Law Students and Lawyers, 1986 A.M. B. Found. RES. J. 225; Susan Daicoff, Lawyer Know Thyself: A Revicw of Empirical Research on Attorney Attributes Bearing on Professionalism, 46 AM. U. L. REV. 1337, 1407 (1997); Matthew M. Dammeyer \& Narina Nunez, Anxiety and Depression Among Law Students: Current Knowledge and Future Directions, 23 LAW \& Hum. Behav. 55 (1999); Gerald F. Hess, Heads and Hearts: The Teaching and Learning Environment in Law School, 52 J. LfGial Educ. 75 (2002); Stephen B. Shanfield \& G. Andrew H. Benjamin, Psychiatric Distress in Law Students, 35 J. Legal Educ. 65 (1985); Kennon M. Sheldon \& Lawrence S. Krieger, Does Legal Education Have Undermining Effects on Law Students.' Evaluating Changes in Motivation, Values, and Well-Being, 22 BEHAV. SCI. \& L. 261 (2004) [hereinafter Sheldon \& Krieger, Does Legal Education Have Lindermining Effects]; Kennon M. Sheldon \& Lawrence S. Krieger, Understanding the Negative Effects of Legal Education on Law Students: A Longitudinal Test of Self-Determination Theory, 33 Personality \& Soc. Psychol. BuLL. 883 (2007) [hereinafter Sheldon \& Krieger, Understanding the Negative Effects].

9. Lynda L. Murdoch, Psychological Distress and Substance Abuse in Law Students: The Role of Moral Orientation and Interpersonal Style 87 (Nov. 2002) (unpublished Ph.D. dissertation, Simon Fraser University) (on file with authors).

10. See Hess, supra note 8 , at 79; Murdoch, supra note 9, at 95-97.

11. Marilyn Heins, Shirley N. Fahey \& Roger C. Henderson, Law Students and Medical Students: A Comparison of Perceived Stress. 33 J. LeGal Educ. 511, 51 1-14 (1983).

12. Nancy J. Soonpaa, Stress in Law Students: A Comparative Study of First-Year, SecondYear, and Third-Year Students, 36 CONN. L. REv. 353, 377-78 (2004).

13. Benjamin et al., supra note 8 , at 245 .

14. Id. at 240 .

15. David R. Culp. Law School: A Mortuary for Poets and Moral Reason, 16 CAMPBell L. REV. 61 (1994); Daicoff, supra note 8, at 1380; Barbara Glesner Fines, Competition and the Curve. 
Law students themselves are becoming aware of how widespread the problem is. The Law Student Division of the American Bar Association recently initiated a Law Student Mental Health Initiative, and it has designated March 27 as "National Mental Health Day" at law schools across the country. ${ }^{16}$ The Chair of the Law Student Division has urged law schools "to sponsor educational programs and events that teach and foster breaking the stigma associated with severe depression and anxiety amongst law students and lawyers." 17 The Association of American Law Schools (AALS) has begun to recognize the importance of these issues as well. In 2006, AALS created a new section, the Section on Balance in Legal Education, to address mental health concerns; this Section presented a program on law student well-being at the most recent AALS Annual Meeting. ${ }^{18}$

Psychologists, lawyers, and scholars have suggested many different ways law school could be a causal factor in student unhappiness. Some researchers have focused on the fierce competition for grades and the singular emphasis on achievement. ${ }^{19}$ Researchers also cite the use of the Socratic method in the classroom and the faculty's emphasis on linear thinking at the expense of student creativity and personal values. ${ }^{20}$ Others have found that law school fosters certain personality traits in its students that can lead to unhappiness, such as defensiveness and pessimism. ${ }^{21}$ Finally, studies have shown that as the school year progresses, students' intrinsic motivation decreases, as does their contact with social support networks. ${ }^{22}$

Given the growing body of literature on law student distress, how have law

65 UMKC L. REV. 879 (1997); B.A. Glesner, Fear and Loathing in the Law Schools, 23 CoNx. L. REV. 627 (1991); Hess, supra note 8, at 77-78; Ann L. Iijima, Lessons Learned: Legal Education and Law Student Dysfunction, 48 J. LegAL Educ. 524, 526-27 (1998).

16. American Bar Association, Law Student Mental Health Initiative, http:/ www.abanet.org/ lsd/mentalhealth/home.html (last visited Apr. 30, 2009).

17. Id.

18. See AALS Section Events, Educating Lawyers and Best Practices for Legal Education: A Mandate to Humanize the Law School Experience, https://memberaccess.aals.org eWeb/ DynamicPage.aspx? ?webcode=SesDetails\&ses_key=67f14eb2-ca05-4a6a-bb9f-4270d482bbdf (last visited Apr. 30, 2009).

19. See Culp, supra note 15 , at 69 ; Hess, supra note 8 , at 78 .

20. Sec Culp, supra note 15, at 62; Daicoff, supra note 8, at 1381; Hess, supra note 8, at 81; Lawrence S. Krieger, What We're Not Telling Law Students-and Lawyers-that They Really . Veed To Know: Some Thoughts-in-Action Toward Revitalizing the Profession from Its Roots, 13 J.L.\& H七ALTH 1, 25-26 (1998).

21. S'' Daicoff, supra note 8, at 1380; Jason M. Satterfield, John Monahan \& Martin E.P. Seligman, Law School Performance Predicted by Explanatory Style, 15 BeHAV. SCl. \& L. 95, 103 104 (1997); Seligman et al., supra note 3, at 54-56.

22. See Iijima, supra note 15, at 526-28; Sheldon \& Krieger, Does Legal Education Have Undermining Effects, supra note 8, at 275-76. 
schools responded? For the most part, they have evinced an awareness of the problem and responded with limited programs to assist law students in distress. Almost universally, however, these programs are reactive; they respond to students' requests for help by directing severely distressed students to a mental health counselor in the student assistance program (SAP) at the university of which the law school is a part. ${ }^{23}$ These programs offer help to those most in need of counseling and assistance, but they suffer from two significant limitations. First, as we discuss in more detail in Part II, the SAPs are primarily designed to provide assistance only when a student is severely distressed; they offer little help in warding off the distress before it reaches a crisis. Second, if law student distress is as prevalent as the studies indicate, SAPs can offer help to only a small percentage of the students who suffer from significant levels of stress and depression. ${ }^{24}$ SAP programs are designed to provide counseling when students come to seek assistance, and only a small percentage of students who are stressed do so. ${ }^{25}$

SAPs are an important, but limited, first step in responding to the high levels of stress and depression in law schools. The question remains, then: what else can be done to aid students in distress or, even better, prevent the problems before they begin? As discussed in greater depth in Part III below, scholars have suggested a number of possible solutions, including restructuring the law school curriculum to provide a greater emphasis on practical skills and less focus on abstract legal theory, altering or eliminating the traditional Socratic method, reducing the size of law school classes, and changing the way in which students are graded. ${ }^{26}$

For reasons that we develop more fully in Part III of this Article, these proposals all have significant limitations or problems. The proposed curricular changes would be controversial because many would regard them as pedagogically unsound, even if psychologically less stressful. Moreover, a curricular shift to more practical and practice-oriented classes runs counter to the increasing trend toward theoretical and interdisciplinary classes. Thus, even if these proposals were good ideas (which they may well be), they would face some stiff opposition from law school faculties. The challenge law schools face is to come up with innovative approaches to the problem of law student distress that do not require a complete overhaul of the law school curriculum.

Fortunately, the relatively new field of positive psychology may provide some useful solutions to the problem where the traditional approaches of clinical psychology and the proposals for curricular reform fail. ${ }^{27}$ The principal tenet of

23. See infra notes 89-112 and accompanying text.

24. See, e.g., infra note 96 and accompanying text.

25. Id.

26. See infra notes 134-155 and accompanying text.

27. The current body of psychological research on student distress mirrors the larger field of 
positive psychology is that to understand the human condition, we should study not only mental illness and distress but also the conditions that lead to optimal functioning. ${ }^{28}$ With this goal in mind, positive psychology focuses its research on the study of "positive emotions, positive character traits, and enabling institutions." ${ }^{, 29}$ Positive psychologists are quick to emphasize that their research is designed to supplement and not to replace traditional psychological research on the causes of psychological suffering. ${ }^{30}$ Rather, it is intended to explore areas that have been neglected by traditional psychology. Although positive psychology researchers were not the first persons to think about what makes for a full and happy life, "the value of the overarching term positive psychology lies in its uniting of what had been scattered and disparate lines of theory and research about what makes life most worth living."

Positive psychology aims to move from a disease model, where the focus is solely on fixing what is wrong with people, to a health model, where the focus is on building positive traits and skills that foster optimal functioning. In terms of law student well-being, this means that we have an obligation to study not only those students who become depressed, but also those who manage to thrive in law school. Law schools should ask the question: in the face of overwhelming stress and the high risk for depression, why do some law students remain happy? This altered focus does not mean that we can now neglect the depressed law students in favor of those who are happy; in fact, finding relief for the distressed law student population is still our chief priority. But by switching our focus to the study of those students who thrive during law school, we can start identifying what characteristics buffer certain law students against depression. Thus, this Article's focus on positive psychology aims to explore not only how schools might reduce the current levels of student distress, but also how they can build in preventative measures that will foster optimal psychological functioning for future classes of law students. In the end, a greater understanding of the individual and societal conditions that lead to optimal levels of well-being will

psychology, especially clinical psychology, in that it focuses only on mental illness--not on the full spectrum of human experience. See Shelly L. Gable \& Jonathan Haidt, What (and Why) Is Positive Psychology?, 9 REV. GEN. PSYCHOL. 103, 105-07 (2005).

28. Id. at 104 .

29. Martin E.P. Seligman et al., Positive Psychology Progress: Empirical Validation of Interventions, 60 AM. Psychologist 410, 410 (2005).

30. Id. As two researchers described it,

positive psychology does not imply that the rest of psychology is negative, although it is understandable that the name may imply that to some people. In fact the large majority of the gross academic product of psychology is neutral, focusing on neither well-being nor distress. Positive psychology grew largely from the recognition of an imbalance in clinical psychology, in which most research does indeed focus on mental illness.

Gable \& Haidt, supra note 27, at 104

31. Seligman et al., supra note 29 , at 410. 
actually better prepare law schools to meet the needs of those who are suffering. ${ }^{32}$

The potential benefits of positive psychology in the field of law student wellbeing have already been suggested by some scholars with varying degrees of reference to the psychology literature. For instance, several articles on law student well-being do not mention positive psychology by name, but do provide advice on how to find "the good life" in the field of law. ${ }^{33}$ Recently, a few psychologists have contributed more directly to this line of inquiry by examining specific characteristics of happy and unhappy law students. ${ }^{34}$ Their focus so far has been on the changes in motivation and values of law students. Their findings suggest that intrinsically motivated activities cultivate greater fulfillment in law school and that decreases in community service values are correlated with decreases in subjective well-being. ${ }^{35}$ Studies have also shown that law students have an increased ability to cope with the stress of looking for a job when they have higher levels of intrinsic motivation and internal attributions for success. ${ }^{36}$

This research is helpful, yet it singles out just a few of the potentially numerous personal characteristics that may differentiate the happy law students from the depressed ones. In their study of attorney discontent, Seligman, Verkuil, and Kang address this vast potential for study through the lens of positive psychology: "Law schools are themselves a potential breeding ground for lawyer demoralization and that makes them-as well as law firms-candidates for reform. In these ways the relationship between positive psychology and law becomes a subject worthy of further study in the legal academy, as well as in the profession at large." 37

This Article aims to respond to this call for action by exploring some of the ways in which the research of positive psychologists may help in reducing law student distress. The positive psychology literature offers a number of methodologies that law schools might utilize to help insulate their students from

\section{Id.}

33. Tim Kasser, Personal Aspirations, the "Good Life" and the Law, 10 DEAKIN L. REV. 33, 34 (2005); see, e.g., James J. Alfini \& Joseph N. Van Vooren, Is There a Solution to the Problem of Laurer Stress? The Law School Perspective, 10 J.L. \& Health 61, 61-67 (1995); Krieger, supra note 20, at 48; Patrick J. Schiltz, On Being a Happy: Healthy, and Ethical Hember of an Unhappy, Unhealthy, and Unethical Profession, 52 VAND. L. REV. 871, 920-51 (1999).

34. See Antonia Abbey, Christine Dunkel-Schetter \& Philip Brickman, Handling the Stress of Looking for a Job in Law School: The Relationship Between Intrinsic Motivation, Intirnal Attributions, Relations with Others, and Happiness, 4 BASIC \& APPLIED SOC. PSYCHOL. 263 (1983): Sheldon \& Krieger, Understanding the Vegative Effects, supra note 8.

35. Abbey et al.. supra note 34 .

36. Id. Someone who is intrinsically motivated pursues activities for their own internal reasons-because the activities are worthwhile in and of themselves -and not for external reasons. like recognition or financial gain.

37. Seligman et al., supra note 3, at 54 . 
stress and depression. Although a complete solution to the problem of law student distress will require much additional research, there are currently enough reliable empirical studies to suggest several promising paths for law schools to explore.

In addition, this Article provides the results of a modest empirical study designed to test, in the law school context, one of the principal tenets of positive psychology research, that the identification and utilization of certain personal strengths buffers individuals against stress and depression and allows them to function at optimal levels. A growing body of research conducted outside of law student populations has suggested that concentrating on one's strengths improves life satisfaction. ${ }^{38}$ Focusing on enhancing these strengths has been associated with numerous positive outcomes in the workplace, including increased employee engagement and well-being. ${ }^{39}$ Research shows that at workplaces where employees believe they have the "opportunity to do what [they] do best," there are significantly higher rates of loyalty and employee retention ${ }^{40}$ and also greater annual employee productivity. ${ }^{41}$

Using the strengths-based approach of positive psychology as the foundation for our study, we hypothesized that the law students who used their top strengths more often in daily life would be the ones to report higher levels of well-being. This was indeed the case: students who found ways to use their top strengths were less likely to suffer from depression and stress and more likely to report satisfaction with life. ${ }^{42}$ Although our study was only correlational, when viewed in light of previous research that shows a focus on strengths can actively improve life satisfaction and lower depression levels in the general population, ${ }^{43}$ it may suggest that a focus on personal strengths can act as a buffer against psychological distress in law school.

We discuss the issues described above in four principal Parts. In Part I, we review the literature on law student distress to present an accurate image of the

38. Alex linley, Average to A+: Realising StreNgths in Yoursflf a\d Others 154 (2008).

39. See, e.g., Marcus Buckingham \& Donald O. Cliftox. Now. Discover Your Strengths 5 (2001); Timothy D. Hodges \& Donald O. Clifton, Strengths-Based Development in Practice, in Positive Psychology in Practice 256, 262-65 (P. Alex Linley \& Stephen Joseph eds., 2004).

40. Buckingham \& Clifton, supra note 39, at 5; James K. Harter, Frank L. Schmidt \& Theodore L. Hayes, Business-Unit-Level Relationship Between Emplovee Satisfaction, Employe' Engagement, and Business Outcomes: A Meta-Analysis, 87 J. APPLIED Psychol. 268, 273-274 (2002).

41. Julie Connelly, All Together Now; Gallup Mgmt. J., Mar. 15, 2002, http:/gmj.gallup.com/content/763/All-Together-Now.aspx.

42. See infia pp. 411-412.

43. Seligman et al., supra note 29 , at 419 . 
extent of stress and depression among law students. In Part II, we present the results of an informal survey of law schools to identify what they are currently doing to respond to issues of student well-being. Our investigations show that although every law school surveyed had access to a university counseling service for seriously troubled law students, very few had significant preventative programs designed to forestall the development of mental health issues among law students. In Part III, we identify the various suggestions scholars have offered to address law student distress and discuss the potential of these solutions as well as the problems associated with the suggestions. Finally, in Part IV, we discuss the relatively new discipline of positive psychology and how law schools might begin to utilize the work of positive psychology researchers to protect students from the stress and depression which affects so many. In particular, we identify three strands of positive psychology research that might be especially helpful in this regard: learned optimism, the "broaden-and-build" theory of positive emotions, and strengths theory. In this Part we also present the results of our own empirical research and offer suggestions on how law schools might incorporate what we learned into positive psychology programs for their students.

\section{THE RESEARCH ON LAW STUDENT DistRESS}

A growing body of research shows that law students have an unusually high level of distress, even when compared to students in other stressful professional programs. In 1957, the first of these studies showed that first-year law students experienced higher levels of anxiety than first-year medical students. ${ }^{44}$ Moreover, the greater levels of anxiety continued throughout law school to the time of graduation. ${ }^{45}$ Subsequent articles reached similar conclusions, but these were largely anecdotal or did not use tested and verified survey instruments. ${ }^{46}$ In 1979, James M. Hedegard conducted an empirically valid, longitudinal study of students at the J. Reuben Clark Law School at Brigham Young University. ${ }^{47}$ Students were tested during the law school's orientation week and then again two

44. See Leonard D. Eron \& Robert S. Redmount, The Effect of Legal Education on Attitudes, 9 J. LEGAL Edu( .431 , 435-36 (1957).

45. Id.

46. See, e.g., Phyllis W. Beck \& David Burns, Anxiety and Depression in Law Students: Cognitive Intervention, 30 J. LEGAL EduC. 270 (1979); Lawrence Silver, Anxiety and the First Semester of Law School, 1968 WIS. L. REV. 1201; Alan A. Stone, Legal Education on the Couch, 85 Harv. L. Rev. 392 (1971); James B. Taylor, Law School Stress and the "Déformation Professionelle," 27 J. Legal Educ. 251 (1975); Andrew S. Watson, The Quest for Professional Competence: Psychological Aspects of Legal Education, 37 U. CIN. L. REV. 93 (1968).

47. James M. Hedegard, The Impact of Legal Education: An In-Depth Examination of CareerRelevant Interests, Attitudes and Personality Traits Among First-Year Law Students, 1979 AM. B. FOUND. RES. J. 791. 
weeks before the end of the second semester. ${ }^{4 x}$ The study found "increases in feelings of psychological distress, internal conflict, [and] anxiety" from the first test to the second. ${ }^{49}$ In addition, the study showed that the scores were significantly higher than predicted based on the scores for BYU undergraduates. ${ }^{50}$

Further studies over the next two decades confirmed and expanded on these findings. ${ }^{51}$ One examination of law students and medical students in their first and third years of school found that depression levels were significantly higher among law students than medical students. ${ }^{52}$ This study found that third-year law students reported even higher rates of depression than first-year law students. ${ }^{53}$ Another comparative study found that law students experienced significantly more academic and fear-of-failing stress than medical students, ${ }^{54}$ disproving the authors' original hypothesis that medical students would be more stressed. ${ }^{55}$ Researchers also found that law students experienced much higher anxiety rates than undergraduate students ${ }^{56}$ and that law students exhibited significantly higher levels of stress and depression than the population at large. ${ }^{57}$

One of the largest studies on law student distress was conducted in 1986 by Andrew Benjamin and fellow researchers at the University of Arizona Law School. ${ }^{58}$ The authors studied 320 students and alumni from the law school, and they used five separate instruments to measure the demographic information and

48. Id. at 809 .

49. Id. at 835 .

50. Id. at 836-37. Scores were elevated somewhat compared to undergraduates even at the start of law school, but were higher by the end of the first year. Id.

51. One positive note is that at least one study has found that "law students commit suicide significantly less frequently than [their] age-matched peers." M.J. Hamilton et al., Thirty-Five Law' Student Suicides, 11 J. PsychiatRY \& L. 335, 342 (1983).

52. Robert Kellner, Roger J. Wiggins \& Dorothy Pathak. Distress in Medical and Law Students, 27 COMPREHE\SIVE PSYCHIATRY 220, 221-22 (1986).

53. Id. at 222 .

54. Heins et al., supra note 11 , at 519.

55. Id. at 522. For yet another study that found the distress of law students to be much greater than that of medical students, see Shanfield \& Benjamin, supra note 8, at 68-70. In this study, the researchers attributed the higher levels of distress among law students to differences in the learning environments between law school and medical school. They noted that while medical school has smaller classes and offers students more individual attention, lan school classes are less personal and professors are more distant. In short, they concluded, "[l]aw school appears to be less nurturant of students than medical school." Id. at 69 .

56. Roseanna McCleary \& livan L. Zucker, Highor Trait-and Stut'-4nxtety in Female Law. Students than Male Luw Students, 68 PSYCHOL. REP. 1075, 1077 (1991).

57. Shanfield \& Benjamin, supra note 8, at $69.7+\mathrm{tbl.1}$.

58. G. Andrew H. Benjamin et al., The Role of Le'gal Education in Producing Psychological Distress Among Law Students and Lawlers, 11 A\. B. Fol NI). REs. J. 225 (1986). 
psychological status of the students at different time intervals. ${ }^{59}$ The researchers found that prior to entering law school, students reported scores within the normal range, but during their first year, law students' average scores increased significantly, indicating elevated levels of psychological distress. ${ }^{60}$ The researchers also found that the "increase in symptoms of law students continued as they progressed through the three years of the program." ${ }^{61}$ Depending on the symptom (which included, among others, depression, anxiety, hostility, obsessive compulsive behavior, and interpersonal sensitivity), $20 \%$ to $40 \%$ of the study group demonstrated significant symptom elevations. ${ }^{62}$ The researchers' bottom line was grim:

Before law school, subjects develop symptom responses similar to the normal population. This comparison suggests that prospective law students have not acquired unique or excessive symptoms that set them apart from people in general. During law school, however, symptom levels are elevated significantly when compared with the normal population. Elevations of symptom levels significantly increase for law students during the first to third years of law school. ${ }^{63}$

Interestingly, the researchers found no correlation between symptom levels and a number of factors that one might have expected to influence student distress. For example, the research found no significant relations between symptom levels and age, undergraduate grade point average, law school grade point average, hours devoted to undergraduate studies, or hours devoted to law school studies. ${ }^{64}$ The researchers concluded that the "pattern of results suggests that certain aspects of legal education produce uncommonly elevated psychological distress levels among significant numbers of law students and recently graduated alumni." 65

The problem of law student distress encompasses not only elevated levels of stress and depression but increased substance abuse as well. In 1993, the Association of American Law Schools Special Committee on Problems of
59. Id. at 228 .
60. Id. at 240 .
61. Id. at 241.
62. Id. at 246.
63. Id.
64. Id.

65. Id. at 247. The University of Arizona researchers suggested a number of possible causes for the significant levels of student distress found in their study. Here, however, they were much less definite about the reliability of their observations. Their tentative hypotheses included: "excessive workloads and time management problems," "chronically high student-faculty ratios, leading to limited interactions." and "unbalanced development of student interpersonal skills." Id. at $248-50$. 
Substance Abuse in the Law Schools ${ }^{66}$ found that American law school students showed a higher regular use of alcohol and certain psychedelic drugs than high school and college graduates of the same age. ${ }^{67}$ The survey also found that $11.7 \%$ of law students had abused alcohol since enrolling. ${ }^{68}$ The survey provided evidence that this substance abuse increases in degree and frequency throughout the three years of law school, especially in the case of alcohol; third-year students reported significantly higher alcohol usage than first- and second-year students. ${ }^{69}$ Based on their surveys, the Committee concluded that "some of the data must be viewed as extremely disturbing and indicative of a continuing problem that demands attention." ${ }^{70}$ The report went on to conclude that a significant portion of law students seem to be using substances to relieve stress and that these patterns may only worsen as these individuals enter pressurized careers in the field of law. ${ }^{71}$

In 1999, two psychologists reviewed the empirical literature on law student distress and made these conclusions:

1) "Anxiety and depression are typically higher among law students than the general population, regardless of which measure was used ."

2) "Contrary to some anecdotal reports, anxiety and depression were not limited to first-year students, as symptom measures were as high or higher for third-year students."

3) "In every published study, law students tended to report higher levels of depression and anxiety than those reported by medical students."

Krieger of Florida State University Law School has been the leading writer on this subject over the past five years. His work with psychologist Kennon Sheldon has explored the anecdotal literature and provided substantial new empirical research confirming the extent of the problem of law student distress. In 2002, Krieger observed, "tales of law student and lawyer depression. overwork, dissatisfaction, alcohol abuse, and general distress are legion, and many of us see, more clearly than we would like, the undoing of our students' collective energy, enthusiasm, and engagement after only a few months of law

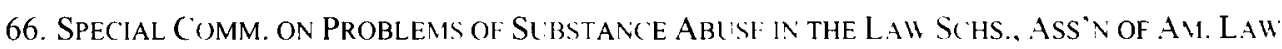
SCHS., REPORT (1993), available at http:/iwww aals.org documents substanceabusereport.pdf.

67. Id. at 8 .

68. Id at 10.

69. Id at 12.

70. Id. at 11 .

71. Id at 12.

72. Dammeyer \& Nunez, supra note 8 , at 67. 
school." 73

In Sheldon and Krieger's first major empirical work, the authors conducted two studies of law students that were designed to determine the extent of law student distress to see how these problems might be solved. ${ }^{74}$ The study took a longitudinal approach in measuring law students at a medium-sized public law school on their first day of law school and subsequently over the course of the spring of their first year and the fall of their second and third years. ${ }^{75}$ An undergraduate comparison sample consisted of students in an upper division psychology course at a different public university. ${ }^{76}$ The researchers used three different study instruments to measure mood, ${ }^{77}$ life satisfaction, ${ }^{78}$ and depression. ${ }^{79}$ They also measured physical health by asking participants to rate eighteen different physical symptoms ("such as runny nose/sore throat, insomnia, and headaches"). ${ }^{80}$ The researchers then created an aggregate subjective wellbeing score for each participant by combining all of these survey results. ${ }^{81}$

The results of the study confirmed two important points about law student distress. First, a comparison of the law students at the beginning of their law school career with the undergraduate students showed no significant problems among the law students. In fact, the entering law students reported higher levels of positive affect and life satisfaction than the undergraduates. The researchers noted that "the most important thing to take from these analyses is that the law students appeared quite happy and healthy at the beginning of their career, with relatively intrinsic and prosocial values." 82 Thus, the study suggested that "consistent with earlier research . . . any later distress among the law students is

73. Lawrence S. Krieger, Institutional Denial About the Dark Side of Law School, and Fresh Empirical Guidance for Constructively' Breaking the Silence, 52 J. LEGAL EDUC. 112, 113 (2002).

74. Id. at 112 .

75. Sheldon \& Krieger, Does Legal Education Have Undermining Effects, supra note 8, at 267.

76. Id.

77. Mood was measured with the Positive and Negative Affect Schedule (PANAS). This measures the quantity and degree of positive and negative emotions an individual is currently feeling. See David Watson, Lee Anna Clark \& Auke Tellegen, Development and Validation of Brief Measures of Positive and Negative Affect: The PANAS Scales, 54 J. PERSONALITY \& SOC. PSYCHOL. 1063 (1988).

78. Life Satisfaction was measured with the Satisfaction with Life Scale. See Ed Diener et al., The Satisfaction with Life Scale, 49 J. PERSONALITY ASSESSMENT 71 (1985).

79. Depression was measured using the Beck Depression Inventory. See AARON T. BECK, COGNITIVE Therapy AND THE EMOTIONAL Disorders (1976).

80. Sheldon \& Krieger, Does Legal Education Have Undermining Effects, supra note 8, at 268.

81. Id.

82. Id. at 271 . 
not an effect of pre-existing distress or problematic personality traits."

Second, the study showed that, over the course of the first year of law school, the study participants "experienced large reductions in positive affect, life satisfaction, and overall [subjective well-being], and large increases in negative affect, depression, and physical symptoms." 84 Looking at the data from the second and third years of law school, the researchers found that the declines in subjective well-being remained constant, with the levels remaining unchanged in both the second and third years. ${ }^{85}$

A second study by these researchers, this time at a private, urban law school, showed a similar decline in law student well-being during the first year, supporting the proposition that the problems observed in the first study may be generalized to other law schools. ${ }^{86}$ Based on the two studies, Sheldon and Krieger concluded:

Past scholarly commentaries and previous studies paint a bleak picture of the effects of legal education on the well-being of law students. Our data from two very diverse law schools confirms these negative reports. If these experiences are common in American law schools, as anecdotal reports and other studies indicate, it would suggest that various problems reported in the legal profession, such as depression, excessive commercialism and imageconsciousness, and lack of ethical and moral behavior, may have significant roots in the law-school experience. ${ }^{87}$

In 2007, Sheldon and Krieger reported an enlarged and extended version of their previous work, which also showed that at the two different law schools studied, subjective well-being declined over the students' time in law school. ${ }^{88}$ This study is the most extensive investigation of law student well-being published to date in two respects. First, it contains study results for classes of students at two separate law schools that differ in significant ways. Second, it reports on data for law student distress longitudinally over the entire law school career of the students studied. It essentially confirms all of the conclusions of Sheldon and Krieger's first study and underscores the need for law schools to take a serious look at what they can do to mitigate the problem of law student distress.

\section{Id.}

84. Id. at 272.

85. Id. at 274 .

86. Id. at 276.

87. Id. at 283 .

88. Sheldon \& Krieger, Understanding the Negative Effects, supra note 8 , at 889 . This study involved a different sample group from a subsequent year's class at the first law school. In addition, the authors gathered additional data from the third year of the law students at the second law school who had been included in the earlier study. Id. at 887 . 


\section{What Law SChOOLS ARE DOING ABOUT LAW STUDENT Distress}

Given the well-documented problems of law student distress discussed in the previous section, it is important to examine possible ways in which law schools can respond to the problem. In this section of the paper we examine the current law school programs for dealing with law student distress.

To get some idea of how law schools have been responding to this issue, we surveyed the websites of the top seventy-five law schools as ranked by U.S. News \& World Report in $2008 .{ }^{89}$ In surveying the websites we looked for information regarding the following possible sources of assistance for law students: 1) whether there was any on-site counseling at the law school: 2) whether the website contained any information about referrals to the undergraduate or main university counseling center or services available through student health insurance; 3) whether the website contained any information regarding the local lawyer assistance program that virtually all bar associations now maintain for lawyers who have psychological or substance abuse problems $;{ }^{90}$ and 4 ) whether the website contained any information about proactive programs or materials designed to help students avoid stress, depression, and other problems affecting student well-being. We supplemented these surveys with calls to the student affairs offices at each law school to determine if the information on the website was complete or if there were additional programs or resources not listed.

Most of the law schools surveyed have no on-site counseling available at the law school itself and refer law students to the university counseling or health center. $^{91}$ There are a few exceptions: Washington University in St. Louis School of Law, which states that it has a licensed professional counselor on staff at the law school; Georgetown, which retains three professional counselors for its campus; the University of Washington School of Law, which states that it has a mental health professional on call; and Loyola Law School (Los Angeles), where

89. Schools of Law: The Top 100 Schools, U.S. News \& WORLD REP., Apr. 7, 2008, at 46-47. For the schools and the pages of their websites that contain information regarding mental health programs, see infra Appendix $C$.

90. The ABA's website maintains contact information for lawyer assistance programs offered by state bar associations. See American Bar Association, Commission on Lawyer Assistance Programs, Directory of CoLAP Programs, http:/www.abanet.org/legalservices/colap/ lapdirectory.html (last visited Apr. 30, 2009). The vast majority of state bars allow law students to take advantage of these programs, but there are some exceptions. Of the thirty-two states and the District of Columbia in which the top seventy-five law schools are located, only three restrict use of the program to members of the bar: Arizona, California, and Oklahoma. In the state of Washington, only third-year law students may use the program. Telephone Interview's by Matthew Albanese with State Bar Representatives (Feb. 18, 2009) (notes on file with the authors).

91. Several of the law schools stressed that university counseling centers were nearby and easily accessible to law students. Additionally, it was mentioned that law students seemed to prefer off-site counseling in order to preserve anonymity. 
a licensed counselor is available on site through the Office of Student Affairs. At eight law schools, counselors hold office hours at certain scheduled times of the week on the law school campus or are available exclusively to law students at the university counseling center. ${ }^{92}$ Additionally, while many law school websites state that counseling is available through the Office of the Dean of Students or Dean of Student Affairs, most schools (via telephone interviews) stated that this counseling takes the form of an initial assessment, after which deans may refer students to the appropriate resource, usually the university counseling center. ${ }^{93}$

Sixty-two of the seventy-five law schools have information on their websites concerning referral to the main university's counseling center for services that are either covered by the student health insurance plan or student activity fees or are free of charge. These references typically provide a description of the counseling and mental health services available along with lists of possible student concerns. While the majority of law school deans stated in phone interviews that they provide students with information regarding the local lawyers assistance program (usually at orientation), only fifteen provide such information on their websites. ${ }^{94}$

This survey suggests that law schools are genuinely aware of the need that many students will have for psychological or mental health counseling and that the university generally provides such counseling. These programs are available to students who seek out help, many of whom can benefit from individual therapy. ${ }^{95}$ It is unlikely, however, that counseling will reach the great majority of students who experience psychological distress. At George Washington

92. These law schools are Chicago-Kent College of Law, Cornell Law School, George Mason University School of Law, George Washington University Law School, Ohio State University Moritz College of Law, Seton Hall University School of Law. University of Alabama School of Law, and the University of Missouri School of Law. Brooklyn Law School does not offer on-site counseling, but its website does list three mental health professionals with whom students can consult. See Brooklyn Law School, Student Health, Mental Health Consultation, http://www.brooklaw.edu/studenthealth/mentalhealth.php (last visited Apr. 1, 2009).

93. This practice is understandable, as most deans stated they are not mental health professionals. However, the depth and length of counseling may vary depending on the nature of the student's problem and the training of the particular dean. At Villanova. for example, the Assistant Dean for Student Affairs is also a licensed counselor.

94. American University Washington College of Law, Boston College Law School, Boston University School of Law, Brooklyn Law School, Chicago-Kent College of Law. Florida State University College of Law, Georgetown University Law Center, Harvard Law School, Indiana University Maurer School of Law (available in the online version of the student handbook), Seton Hall University School of Law, Temple University Beasley School of Law, University of California Hastings College of the Law, University of Miami School of Law, University of Minnesota Law School, and Villanova University School of Law.

95. See Phyllis W. Beck \& David Burns, Anxient and Depression in Law Students: Cognitive Intervention, 30 J. LEGAL EDUC. 270, 270-73 (1979). 
University Law School, for example, only sixty law students utilized the university counseling services during the past year. ${ }^{96}$ Our own study of George Washington University law students and previous empirical research indicate that far more than sixty law students likely experienced significant problems with stress and depression over this period. ${ }^{97}$ Moreover, counseling services, while certainly necessary, address the problem only once a student is already fairly seriously distressed; they do nothing to head off the development of psychological issues in the first place. Finally, at least one study has found that law students are significantly less likely than medical students to seek out psychological help. ${ }^{98}$ Thus, counseling alone seems insufficient to address the problem of law student distress.

To determine whether law schools have developed any programs for dealing proactively with the problem of law student distress, we surveyed the law schools' websites to try to identify specific programs or resources devoted to such prophylactic mental health resources. Of the seventy-five law schools we surveyed, only a handful had any indications on their websites of programs or materials of this type. ${ }^{99}$ In addition, we made telephone calls to the various Offices of Student Life or Student Affairs, which confirmed the results of the website survey that indicated most law schools have not developed formal programs to deal with student distress in a preventative way. We list below some steps that law schools have taken to address proactively the problems of student distress.

Some of the most popular measures include advertising wellness activities hosted by the law school and university, including athletic and spiritual offerings. Columbia Law School runs a "Wellness Wednesday" program, ${ }^{100}$ and Georgetown Law offers various services designed to "promote a positive

96. Interview with Renee DeVigne, Dean of Student Affairs, George Washington Univ. Law Sch., in Wash., D.C. (Dec. 1, 2008).

97. For the results of our own empirical study of George Washington University law students, see infra text accompanying notes 316-344. See also the empirical research cited supra notes 47 , $54,57,58,73 \& 88$.

98. See Heins et al., supra note 11 , at 520-21.

99. Examples of such sites include Harvard Law School's "Wellness@Law"webpage, which provides online links to resources that are designed to offer information about how to maintain "healthy living" and promote wellness, Harvard Law School, Wellness@Law, http://www.law.harvard.edu/current/student-services/wellness/index.html (last visited Apr. 1, 2009), and the wellness section of Comell Law School's website, which recognizes "that teaching habits which foster good health and effective time and stress management skills is a critical part of legal education," Cornell University Law School, Student Resources, http://www.lawschool.cornell.edu/studentlife/resources.cfm (last visited Apr. 1, 2009).

100. See Columbia Law School, Health and Wellness Programs, http://www.law.columbia.edu/current_student/student_service/Health_and_Well (last visited Apr. $1,2009)$. 
lifestyle," including relaxation techniques, counseling, and campus ministries. ${ }^{101}$ At Fordham Law School, free weekly mindfulness and yoga classes are offered to students and faculty as a way to "release some of the tension that is a natural part of studying and working at a law school."102 The University of Miami School of Law instituted its First Annual Wellness Week in the fall of 2007 in order "to promote positive choices about work-life balance and provide resources that support [the] ability to make these choices." 103

Several law schools also distribute literature to incoming students about the potential hurdles in law school and techniques to deal with stress. Through its "Humanizing Law School" webpage, Florida State University College of Law maintains several articles by Professor Lawrence Krieger that deal with issues from grades and teaching techniques to depression and career satisfaction, to give students "some perspectives and advice about the issues of health and life/career satisfaction as a law student and lawyer." 104 At the University of Maryland, the Assistant Dean for Student Affairs distributes Professor Krieger's pamphlet on student stress ${ }^{105}$ and discusses it when she meets with all first-year law students in small groups for lunch. ${ }^{106}$

Perhaps most advanced in its efforts to prevent law student distress, Vanderbilt University Law School has actually incorporated an optional noncredit course called "Supportive Practices" into its first-year curriculum. ${ }^{107}$ About thirty students meet one hour per week during the first semester and are taught strategies for dealing with issues like stress, anxiety, and setting realistic

101. See Georgetown Law, Center for Wellness Promotion. http://www.law.georgetown.edu/wellness/ (last visited Apr. 1, 2009).

102. See Fordham Law, Wellness, http://law.fordham.edu/ihtml/sa-2wellness.ihtml?id=1+33 (last visited Apr. 1, 2009).

103. University of Miami School of Law, Wellness Initiatives, http: иши.law.miami.edu dos/ds_05.php?op=5 (last visited Apr. 1, 2009).

104. Florida State University College of Law, Student Resources. http:/www.law.fsu.edu/academic_programs/humanizing_lawschool/studentresources.html (last visited Apr. 1, 2009); see also Florida State University College of Law. Resources for Teachers \& Administrators, http://www.law.fsu.edu/academic_programs humanizing_lawschool teacher resources.html (last visited Apr. 1, 2009). The law school notes that the division between student and teacher resources is "not absolute" and that students or faculty may "find helpful information in either area." Florida State University College of Law. Humanizing Law School, http://www.law.fsu.edu/academic_programs/humanizing_law'school/humanizing_lawschool.html (last visited Apr. 23, 2009).

105. LaWrenc1: S. Krieger, The Hidden SOURCES of LaW' S(HOOL Stress (2005), arailable at $\mathrm{http} / /$ www.law.fsu.edu/academic_programs/humanizing_lawschool/images'ep.pdf.

106. Telephone Interview with Dawna Cobb, Assistant Dean for Student Affairs, Univ. of Md. Sch. of Law (June 9, 2008).

107. Telephone Interview with Julie Sandine. Assistant Dean for Student Affairs. Vanderbilt Univ. Law Sch. (June 12, 2008). 
performance expectations; various works of Professor Krieger are utilized. ${ }^{108}$ The course extends five weeks into the second semester in order to cover the period when first-semester grades are released. ${ }^{109}$ The law school has added a second "Supportive Practices" class to accommodate a large number of requests from students. ${ }^{110}$

Vanderbilt's approach appears to be unique. Most law schools seek to promote mental health and alleviate distress among the student body through a combination of the following methods: holding "wellness" events sporadically or at specific times, such as before exam period or during the release of grades; establishing peer mentoring or counseling programs; encouraging students to participate in sports, student groups, or community activities; providing academic counseling and informational events (under the assumption that well-informed students are less likely to experience stress or anxiety); informing students of the available personal and emotional counseling resources and distributing related materials and literature; and letting students know that there is always someone available to talk. ${ }^{111}$ Law school deans stated that these methods have met with varying success. Indeed, the success of a program at one school may vary from year to year, with student participation cited as the most common (and unpredictable) variable affecting that success. ${ }^{112}$

As this discussion suggests, law schools are only beginning to think proactively about ways to forestall student mental distress. It is possible that our research may not have captured all that the law schools, or the universities, are doing to help students deal with stress, depression, and other forms of law school distress. Nevertheless, our review of law school websites, supplemented by our calls to the offices of the deans of student affairs, provides a fair indication that the main focus of law schools is to help students by providing counseling service for those who are seriously distressed rather than through the provision of proactive programs designed to ward off law student distress. Law schools have not yet responded to the need for major action to prevent the development of stress and depression among their students.

\section{The Causes of Law Student Distress}

Before we can suggest how law schools may be able to address law student

108. Id.

109. Id.

110. Id.

111. These approaches have been compiled from phone interviews with deans at the various law schools.

112. According to deans and directors of student affairs, low participation in a program resulted from any number of familiar reasons on the part of law students: time constraints, apathy, dubiety that a program would really help, and fear of the stigma of seeking help. 
distress in a proactive way, we must first address the question of what it is about the law school experience in particular that may be causing such a problem. In this Part we examine the literature on law student distress in order to assess the solutions that have been proposed to deal with this problem. Unfortunately, the current literature suffers from two significant problems. First, while we are beginning to see significant empirical data on the kinds and levels of law student distress, there has been little empirical research on the causes of the problem. Second, many discussions of the law school environment and its relation to law student well-being are parts of larger critiques of how law is taught and how the substance of what is taught should be changed. In these critiques, the issue of law student distress is simply a subsidiary argument for change.

A common target of critics looking for the source of law school stress is the Socratic method and other teaching styles that put pressure on students to perform in front of their peers. ${ }^{13}$ Krieger argues that the use of the Socratic method of case analysis "can leave even strong students with a baseline sense of incompetence if emphasized to the exclusion of the many other skills that students know will be necessary for law practice." 114 Even worse, the Socratic method can invite daily feelings of anxiety and fear for law students, especially when the technique is used harshly by aggressive professors. ${ }^{115}$ Stephen Halpern, a political science professor who went to law school, charges law school pedagogy with engendering "psychological insecurity" and inhibiting "curiosity and genuine intellectual interest .... In such an environment independent and critical thinking by students is unlikely." 116

Criticisms of the Socratic method have come from professors seeking to remake the legal educational experience ${ }^{117}$ and from students who found the experience to deaden creativity. ${ }^{118}$ Other objections have focused upon the impact of the Socratic method on students' personal lives and relationships. ${ }^{119}$ Some writers complain that the Socratic method exalts "criticism over imagination," "20 while others have argued that "impressionistic studies of law school have identified a narrowing of interests toward the analytic skills used by

113. See Culp, supra note 15, at 62; Hess, supra note 8, at 81; Krieger, supra note 20 , at 25.

114. Krieger, supra note 20, at 25.

115. Id.

116. Stephen Halpern, On the Politics and Pathology of Legal Education, 32 J. LEGAL EDUC. 383. 389 (1982).

117. See Paul N. Savoy, Toward a New Politics of Legal Education, 79 Y ALE L.J. 444. 460 (1970).

118. Robert Stevens, Law School and Law Students, 59 VA. L. REv. 551, 610-11 (1973).

119. See Anthony J. Mohr \& Katherine J. Rodgers, Legal Education: Some Student Reflections, 25 J. LEGAL EDUC. 403, 412-13 (1973).

120. Howard S. Erlanger \& Douglas A. Klegon, Socialization Effects of Professional School, 13 LAW \& SOC "Y REV. 11, 14 (1978). 
practitioners and away from a broader concern with social values and creative use of intelligence." ${ }^{21}$ Psychologists also question the use of the Socratic method-Andrew Watson noted that "since most professorial responses are questions, they are perceived as never-ending demands, and hoped-for relief never comes into sight. Such a technique runs counter to all learning theory." 122 To date, however, there appears to be no empirical research that supports the conclusion that the Socratic method is to blame for law student distress. ${ }^{123}$

Commentators have criticized not only the method of teaching, but also the substance of what is taught in law schools. We also have (with one major exception discussed below) ${ }^{124}$ little empirical research on this issue and instead have only a good deal of anecdotal commentary and polemical advocacy. For example, in their recent book on the legal profession, ${ }^{125}$ Jean Stefancic and Richard Delgado argue that lawyer discontent begins in law school and has two elements: "A conceptual dimension, concerned with how they understand what they do, and a phenomenological one that embraces the felt experience of law and lawyering." 126 These problems are caused by legal formalism, which is "associated with a form of education that emphasizes doctrines and cases and minimizes external factors, such as justice, social policy, and politics. It imagines law as an autonomous discipline existing apart from others; it is not at all interdisciplinary." 127 Stefancic and Delgado find the source of lawyers' unhappiness in law school and the hyper-competitive environment that students face there. ${ }^{128}$

The authors argue that law students are afflicted by a range of mental health problems because of the inconsistencies and sterility of legal formalism. ${ }^{129}$ The authors also cite as causes of law student distress the demands of large and growing law firms for students to be trained to suit their needs and the insistence of the ABA's MacCrate Report on the need for more practical legal education. ${ }^{130}$

121. Thomas A. Willging \& Thomas G. Dunn, The Moral Development of the Law Student: Theory and Data on Legal Education, 31 J. LEGAL EDUC. 306, 338 (1981).

122. Watson, supra note 46 , at 123.

123. See Dammeyer \& Nunez, supra note 8 , at 71.

124. See discussion infra notes 139-144 and accompanying text.

125. See Jean Stefancic \& Richard Delgado, How Lawyers lose Their Way: A Profession Fails ITS CREATIVE Minds (2005).

126. Id. at 29.

127. Id. at 35 .

128. Id. at 63 .

129. Id. at 63-64.

130. See Am. Bar Assoc., Section of Legal Educ. \& Admissions to the Bar, Legal Education and Professional Dilelopment-An Edlcational Continuum (1992), available at http:/www.abanet.org/legaled/publications/onlinepubs/maccrate.html. This report is often called the "MacCrate Report," referring to Robert MacCrate, the Chair of the Task Force that published the report. 
Finally, the authors complain that the widely-discussed critiques of judges like Judge Harry Edwards stating that law schools are becoming too detached from the practice of law have exacerbated the problem. ${ }^{131}$ All of these factors contribute, the authors contend, to cynicism and depression among law students. ${ }^{132}$

It is far from clear, however, that legal education demands a formalistic approach, much less that this approach is a significant cause of law student distress. As Theresa Beiner has noted, non-formalism involving extra-legal knowledge plays a significant role in legal education and even in the practice of law, so law schools are hardly bastions of a purely formal legal approach. ${ }^{133}$ Moreover, other commentators take the opposite approach from Stefancic and Delgado and argue that it is precisely the increasingly abstract and theoretical approach of modern law schools that exacerbates the decline of law students' subjective well-being. For example, Sheldon and Krieger argue that

law schools traditionally emphasize theoretical scholarship and the teaching of legal theory, and many hire and reward faculty primarily based on scholarly potential and production. Our findings suggest that schools will benefit from reevaluating faculty priorities regarding such issues and from considering carefully the effect of their teaching methods and practices on students. Changes toward employing faculty with more teaching and lawyering (including public service) experience, offering a balance of practical skills training, or providing more training and rewards for teaching excellence might also ultimately enhance students' sense of autonomy and engagement. ${ }^{1: 4}$

The anecdotal criticisms of both the Socratic method and the substance of what is taught in law schools do not offer much in the way of a clear solution to the problem of law student distress. On the whole, they lack a solid empirical foundation, and many of them seem to be vehicles for larger political statements. Moreover, as a practical matter, it is unlikely that law schools will abandon the use of the Socratic method. As David Culp has noted, the practice of Socratic techniques today is virtually the same as it was in the 1970s, or, for that matter, as it was in the $1870 \mathrm{~s} .{ }^{135}$

There also appears to be good reason for retaining the Socratic method. at least in the first year and basic courses. The recent Carnegie Commission Report

131. See Harry T. Edwards, The Growing Disjunction Between Legal Education and the Legal Profession, 91 MICH. L. RI.V. 34, 58 (1992).

132. Stefancic \& Delogado, supra note 125 , at 44-45.

133. Theresa M. Beiner, Insights into the Woes of a Profession, 20 Geo. J. Legal Ethics 101. 119 (2007) (reviewing SIEFANCIC \& DELGADO, supra note 125).

134. Sheldon \& Krieger, Understanding the Negative Effects, supra note 8, at 894-95.

135. Culp. supra note 15 , at 72 . 
on Legal Education ${ }^{136}$ praises the Socratic method as the "signature pedagogy" of the legal education process, which should remain the cornerstone of legal education. ${ }^{137}$ Although the Commission offers plenty of recommendations for how best to implement the Socratic method, the report's bottom line is decidedly positive. The report compares the Socratic method to "a master artisan guiding a roomful of novices through the early stages of learning a craft. . . Only through question and answer can instructors make their thought processes explicit, observable, and available for imitation by students." 138

Perhaps the problem lies not in the teaching method, but in the substance of what is taught in law schools. As mentioned above, there is one recent survey that identifies the substance of what law schools teach as a major cause of student alienation. Elizabeth Mertz, an anthropologist, law professor, and Senior Fellow at the American Bar Foundation, has published the results of a study of first-year contracts classes at eight different law schools. ${ }^{139}$ Mertz studied classes taught by professors with widely varying backgrounds and teaching styles. ${ }^{140}$ She found that in all of the classes students were taught to "think like lawyers" by discounting their own moral values, setting aside their own feelings of empathy and compassion, and substituting a strictly analytical and strategic mode of thinking. ${ }^{141}$ Based upon her observations, Mertz concludes that law school has the "goal of changing people's values" 142 and encouraging students to unmoor themselves from moral reasoning. ${ }^{143}$ The result of this approach, according to Mertz, is that students lose their sense of self and become analytically and emotionally detached. ${ }^{144}$

If Mertz's analysis is correct, it is not difficult to see why law school education could lead to stress, depression, and a loss of individual identity. Krieger finds Mertz's research to be a compelling explanation for the sources of law school stress ${ }^{1+5}$ and argues that the consequences of legal education are "desocializing pressures on student personality" that destroy subjective wellbeing and contribute to ethical and interpersonal problems in the legal

136. See William M. Sullivan et al., Educating Lawytrs: Preparation for the PROFESSION OF LAW (2007).

137. Id. at $23,74-75$.

138. Id. at 62-63.

139. See Elizabeth Mertz, The Language of Lail School: Learvi`g To "Think Like a LAWYER" 4 (2007).

140. Id. at 94 .

141. Id. at 6,95 .

142. Id. at 1 (quoting Shirley Brice Heath, Ways with Words: Language, Life, and WORK IN COMMUNITIES AND (LASSROOMS 367-68 (1983)).

143. Id. at 1,6 .

144. Id. at 99.

145. Lawrence S. Krieger, Human Nature as a New Guiding Philosophy. 47 WaSHBURN L.J. 247, 266-67 (2008). 
profession. ${ }^{146}$ The most discouraging aspect of Mertz's study was the ubiquity of the problems she observed and the extent to which her findings were independent of teaching style. Even if we were certain that Mertz had located a key source of stress and depression, it would not be an easy matter to change the substance of what is taught in every law school. Nor would it necessarily be in the best interests of legal education and the training of prospective lawyers to make radical alterations to the substance of the legal curriculum.

Even if law professors learn how to implement the Socratic method as sensitively and carefully as one might hope, and even if they work to humanize legal education, a number of additional stress factors remain in law students' daily lives. Many commentators have pointed out the problems stemming from the fierce competition for grades and the heavy workload borne by those who struggle to achieve them. ${ }^{147}$ David Culp has argued that the "competition and fear of the almighty evaluator, the grade, cripple creative functioning in the classroom." 148 Krieger, in writing to law students about possible sources of stress, acknowledged that

[y]our entire class shares the pressure to be in that exclusive Top Ten Percent (and to be invited to law review), and you all know that ninety percent of you cannot succeed in this endeavor. . . If you allow these concerns to dominate your thinking, your studies are fraught with anxiety and unease about your worth, your future, and your job prospects. It is as if your whole life is riding on your grades. And this persistent insecurity in turn can create much more stress, by causing you to overwork and abandon your life balance. ${ }^{1+4}$

Gerald Hess echoed this concern when he wrote in 2002 that because "[g]rades and class rank are significant gatekeepers to the reward system during and after law school-law review membership, research or teaching-assistant positions, internships and jobs," competition for them creates enormous stress, fear, and for many, "a profound loss of self-esteem." expect grade pressures to affect medical students and undergraduates as well. there may be something unique (although, as yet unidentified) about the law school environment that makes these pressures more severe.

Added to the stress of intense competition is the related stress created by a heavy workload. As Hess notes, "[t]he workload overwhelms many law students. They have little time for sleep, relaxation, and relationships with friends and family. The demands of the first year cause many of them physical and

146. Id. at 269-70.

147. S'e' Culp, supra note 15, at 70-72; Daicoff, supra note 8, 1389; Fines, supra note 15, at 884; Hess, supra note 8 , at 78.

148. Culp, supra note 15 , at 71 .

149. KRIEGER, supra note 105 , at 3.

150. Hess, supra note 8 , at 78 . 
psychological exhaustion." 151 Stephen Halpern has also argued that excessive workload is a major cause of law student distress:

It is not uncommon for the workload to be such that it is physically impossible to complete assignments on time. For the many highly motivated first-year students this can lead to a near constant state of anxiety. Physical and psychological exhaustion are, I think, programmed into the first year The student is stripped naked, so to speak, so that he may be remade a lawyer. The underlying dynamic, I suspect, parallels the highly structured, controlling. emotionally intense initiatory rites used by the church or the military in the indoctrination of their neophytes. ${ }^{152}$

The problem with solving these potential causes of law school stress and depression is that they are very difficult to remedy directly. For example, although some commentators have suggested that there should be a reduced use of traditional grading methods in order to decrease competition, ${ }^{153}$ it seems unlikely that most law schools will abandon traditional grading methods. Legal educators, law students, and those who hire students directly out of law school all seem to agree that some form of grading system is necessary in order to sort candidates for hiring. ${ }^{154}$ Yale Law School may be able to ensure its graduates obtain job offers without traditional grades, but few other law schools are able to emulate Yale's model. ${ }^{155}$ As long as law school remains graded and law students compete for select jobs, it will be difficult to eliminate these factors as causes of stress.

The empirical studies of law student distress offer a somewhat better substantiated analysis of the causes of distress, but even they tend to rely heavily on the anecdotal literature in identifying causal factors. For example, the study by Benjamin and fellow researchers at the University of Arizona concluded that "the results of the study do show that many [students] do feel overwhelmed by the workload." 156 The researchers also found that "the time management issue, as

\section{Id.}

152. Stephen C. Halpern, On the Politics and Pathology of Legal Education, 32 J. LEGAL Educ. 383, 388-89 (1982).

153. See, e.g., Fines, supra note 15: Hess, supra note 8 , at 79.

154. In a discussion before a recent moot court final argument at George Washington University Law School, Justice Scalia and two distinguished circuit judges agreed that the abandonment of grades was not a realistic possibility for the vast majority of law schools. Justice Antonin Scalia, Judge Marsha Berzon \& Judge Jeffrey Sutton, Question and Answer Session Before the Final Round of the 59th Annual Jacob Burns Van Vleck Constitutional Law Moot Court Competition at the George Washington University Law School (Jan. 22, 2009).

155. Harvard has recently abandoned letter grades (joining Stanford and Berkeley). but there is no indication that this is a trend that is catching on at other law schools, particularly those outside of the traditional "top ten" schools.

156. Benjamin et al., supra note 8 , at 248 . 
shown by the current study, also affects other law students and alumni long after the first year of law school ends." 157 The authors of the study, however, do not have any strong empirical evidence that the workload is what causes high levels of stress and depression among law students. Given that a number of studies show law students' distress to be much higher than that of medical students, despite similarly heavy workloads, it is unlikely that the quantity of work in law school is the main problem.

The Benjamin study notes that the high student-faculty ratio and the low frequency of student-teacher interactions could also be a cause of student distress. ${ }^{158}$ The researchers also suggest that "unbalanced development of student interpersonal skills is the last category of suspect contributors that could lead to impaired psychological well-being." ${ }^{159}$ With respect to each of these issues, however, the researchers' support comes mainly from the anecdotal literature on law student distress and not from their own empirical research.

In Sheldon and Krieger's first study, published in $2004,{ }^{160}$ the focus was principally upon identifying the extent of law student distress, rather than clearly identifying the causes of that distress. The authors did conclude, however. that although the answer to the question of what causes law student distress is complicated, the data they obtained suggests that a shift in motivation and values may be part of the equation. ${ }^{161}$ For instance, they found that over the course of their first year in law school, students move away from an emphasis on community service values and move toward a focus on appearance and image. ${ }^{162}$ Students also experience a shift in motivation from internal to external; that is. they report pursuing goals less for their own enjoyment and more to meet the expectations of others. ${ }^{163}$ Although the authors did find some correlation between changes in motivation and subjective well-being, they admitted that causality could not be determined. ${ }^{164}$

Sheldon and Krieger's second study ${ }^{165}$ made more of an effort to correlate the decline in law students' mental health with factors that might be ameliorated in order to improve law students' well-being. This study evaluated whether selfdetermination theory could provide insights into the causes and possible cures for the declines in law student subjective well-being. ${ }^{166}$ Self-determination theory is

157. Id. at 249

158. Id.

159. Id. at 250

160. Sec Sheldon \& Krieger, Loes Legal Education Have Lindermining Effects, supra note 8.

161. Id.

162. Id.

163. Id. at $280-81$

164. Id. at 281

165. Sheldon \& Krieger. L'inderstanding the Negative Effects, supra note 8.

166. Id. at $8 \times 4,894$. 
concerned with human motivation and the degree to which people's actions are determined by free choice and inner beliefs (intrinsic motivation) or by outside forces and external rewards (extrinsic motivation). ${ }^{167}$ For intrinsic motivation to be present in subordinate individuals like law students, authority figures must provide "autonomy support." In this context, autonomy support in law school would have three important characteristics: 1) "choice provision," in which students are presented with as much choice as possible; 2) "meaningful rationale," in which students are helped to understand the situations where they have no choice; and 3) "perspective taking," in which students feel that their point of view is valued and considered by their school's professors and administrators. ${ }^{168}$

Sheldon and Krieger postulated that satisfaction of these psychological needs that form the basis of self-determination theory would be correlated with improved subjective well-being and negatively correlated with measures of student distress such as depression. Based upon their survey results, Sheldon and Krieger concluded that "autonomy support predicted . . . higher subjective wellbeing relative to baseline, better graded performance controlling for undergraduate GPA and more self-determined motivation to pursue the upcoming legal career."169 Those students who rated faculty within their program as more controlling experienced declining psychological need satisfaction. ${ }^{170}$

What then are the implications of Sheldon and Krieger's conclusion for law schools? The authors suggest that

to maximize the learning and emotional adjustment of its graduates, law schools need to focus on enhancing their students' feelings of autonomy. Why? Because such feelings can have trickle-down effects, predicting changes in students' basic need satisfaction and consequent psychological well-being, effects that may also carry forward into the legal career. ${ }^{171}$

Exactly how to accomplish this change, however, is a vexing problem. The

167. As Sheldon and Krieger describe:

This theory, and its 30-year empirical research tradition, focuses on the contextual and personality factors that cause positive and negative motivation, with corresponding positive and negative performance and subjective well-being (SWB) outcomes. Because the theoretical focus of [self-determination theory] is related to many of the above propositions and critiques. we hope that applying this theory might shed new light on the law school conundrum, as well as suggesting concrete ways to ameliorate the various problems.

Sheldon \& Krieger, Does Legal Education Have Undermining Effects, supra note 8, at 263.

168. Sheldon \& Krieger, Understanding the Vegative Effects, supra note 8, at 884.

169. Id.

170. Id. at 893 .

171. Id. at 894 . 
authors propose that law schools should reconsider their emphasis on theoretical scholarship and teaching of legal theory as well as their hiring and promotion practices that currently emphasize "scholarly potential and production." 172 That prescription, however, as previously noted runs directly against the prevailing opinion in the legal academy, and it would be a difficult prescription for any law school to adopt. The authors' additional suggestion that "employing faculty with more teaching and lawyering (including public service) experience, offering a balance of practical skills training, or providing more training and rewards for teaching excellence" similarly bucks the trend in law school hiring and curricula development. ${ }^{173}$

Thus, it seems clear that a solution to the problem of law student distress is unlikely to come from a major restructuring of law school teaching methods or the relationship between law students and their professors. It is not that these subjects do not deserve attention or that improvements in these areas would not be welcomed by law students. Rather, the practical problems with achieving major changes in these areas seem insurmountable. Instead, the solution to law student distress seems much more likely to be found in programs that help students create buffers against stress and depression that will help them to resist the difficult environment of law school, regardless of the specific causes.

One example of such a program was reported by researchers Richard Sheehy and John Horan. ${ }^{174}$ These researchers developed a stress inoculation training program for first-year law students. As described by the researchers, stress inoculation training typically involves three phases:

First, participants are educated about the sources of their stress, including. for example, its relationship to irrational thinking and possible ways to reduce it at both the physiological and psychological levels. Next, coping skills directed toward specific stressors are fostered. These include, for example, relaxation techniques and cognitive restructuring. (Here, we tailored the coping skills to the individual stressors identified in the law school experience, i.e.. competition, lack of feedback, instructional methods, value conflicts, and myths.) The final application phase involves exposure to real or simulated situations for practice in using the coping skills. ${ }^{175}$

The study involved twenty-two students who participated in stress inoculation training. Participants met with counselors for weekly sessions of ninety minutes each. The first session focused on the education phase of the training; the students were told about the possible sources of stress and anxiety

172. Id.

173. Id.

174. Sce Richard Sheehy \& John J. Horan. Effects of Stress Inoculation Training for 1st-Year Law Students, 11 INT'L J. Stress MgMt. 41 (2004).

175. Id. at 44 . 
and given information on breathing exercises. The next two sessions dealt with the coping skills training and included homework assignments to help them practice the techniques. In the fourth and final session, the students reviewed the previous sessions and engaged in role-playing to test the application of the newly-learned skills. ${ }^{176}$

The researchers found that all participants in the study showed declines in stress and anxiety and that they exhibited significantly lower stress and anxiety levels than the control group of students, who received no special training at all. ${ }^{177}$ Also, more than half of the students in the stress inoculation training reported significant improvements in their predicted class rank. The bottom line, according to the researchers, was that the "study had the support of the law school administration, and was thus easily implemented .... If other schools incorporated the principles of [stress inoculation training] into their curricula and other programs, perhaps both students and graduates would experience less occupational stress as well as improved academic and professional success."178

We think that these researchers are on the right track, and we believe that the science of positive psychology can provide the means to create these stress and depression buffers for law students and help them to enjoy a more productive, meaningful, and satisfying law school experience.

\section{What the Science of Positive Psychology Can Teach LaW Schools}

\section{A. What Is Positive Psychology, and Why Should We Care?}

Positive psychology is the study of the traits and conditions that lead to human thriving. It is often characterized as the study of happiness, but it is more accurately the study of all positive emotions and character traits, including joy, contentment, gratitude, optimism, and resilience. Positive psychologists are quick to emphasize that their research is intended to supplement and not to replace traditional psychological research; it is designed to explore areas that have been neglected by traditional psychology to portray a more accurate and in-depth picture of the range of human experience. While traditional psychology focuses on what makes people distressed and how they can get back to neutral, positive psychology focuses on how people can move above neutral. ${ }^{179}$ It presupposes

176. Id. at $47-48$.

177. Id. at 49 .

178. Id. at 52 .

179. Gable \& Haidt, supra note 27 , at 104 . As two researchers described it:

[P]ositive psychology does not imply that the rest of psychology is negative, although it is understandable that the name may imply that to some people. In fact, the large majority of the gross academic product of psychology is neutral, focusing on neither well-being nor distress. Positive psychology grew largely from the recognition of an 
that happiness and well-being are not merely the absence of depression and anxiety, but rather are a whole host of states, traits, and emotions that combine to make life worth living.

Although the field of positive psychology draws upon research conducted by many traditional psychologists over the past half century, ${ }^{180}$ it has been identified as a separate field of study for about ten years. It first gained widespread attention in 1998 when Martin Seligman devoted his first speech as president of the American Psychological Association to the topic and then published a special positive psychology issue of American Psychologist (the official journal of the American Psychological Association) in January 2000. ${ }^{181}$ Since that time, numerous books and hundreds of articles have been published on positive psychology. ${ }^{182}$ Positive psychology centers have been established at a number of universities, ${ }^{183}$ and positive psychology courses are offered at both the undergraduate and graduate levels at dozens of universities in the United States and Europe. ${ }^{184}$ The University of Pennsylvania now offers a Master of Applied Positive Psychology degree. ${ }^{185}$ Information on positive psychology is spreading to the general public as well. There are now a number of websites devoted to positive psychology, ${ }^{186}$ and there is even a growing interest in positive

imbalance in clinical psychology, in which most research does indeed focus on mental illness.

Id.

180. Id

181. Martin E.P. Seligman \& Mihaly Csikszentmihalyi, Positive Psichology: An Introduction, 55 AM. PSYCHOLOGIST 5 (2000).

182. See, e.g., A Psychology of Human Strengths (Lisa G. Aspinwall \& Ursula M. Staudinger eds., 2003); FlourISHING (Corey L.M. Keyes \& Jonathan Haidt eds.. 2003); HandBooK of Methods In Positive PSYChology (Anthony D. Ong \& Manfred H.M. van Dulmen eds.. 2007); Positive Psychological Assessment: A Handbook of Models aNd Me asl Res (Shane J. Lopez \& C.R. Snyder eds., 2003); Positive Psychology in Practice (P. Alex Linley \& Stephen Joseph eds., 2004); Seligman, supra note 1; The Handbook of Positive Psichologi (C.R. Snyder \& Shane J. Lopez eds. 2002).

183. Among them are the University of Pennsylvania, the University of Michigan. the University of Illinois, and Claremont Graduate University. See Seligman et al., supra note 29, at 413.

184. Id. At Harvard University, for example, the Positive Psychology course taught by Tal D. Ben-Shahar is now the most widely taken undergraduate course, having displaced Introduction to Economics. Se' Carey Goldberg. Han'ard's Crowded Course to Happiness: 'Positive Psychology' Draws Students in Droves, BOSTON GLOBE, Mar. 10. 2006, at A1, available at http://www.boston.com/news/local/articles/2006/03/10/harvards_crowded_course_to_happiness.

185. See Penn College of Liberal \& Professional Studies, Master of Applied Positive Psychology, http://www.sas.upenn.edu/cgs/graduate/mapp (last visited Apr. 1, 2009). One of the coauthors of this article is a graduate of this program.

186. See Happier.com, http:/ www.reflectivehappiness.com (last visited Apr. 1, 2009); Positive Psychology News Daily, http://pos-psych.com (last visited Apr. 17, 2009); University of 
psychology within the popular media. ${ }^{187}$

There are three essential subjects in the study of positive psychology: 1) positive individual characteristics (strengths and virtues), 2) positive subjective experience (happiness, pleasure, and meaning), and 3) positive institutions and communities. ${ }^{188}$ First, positive psychologists have attempted to identify and substantiate the existence of certain cross-cultural character strengths that can provide a basis for human happiness and flourishing. Two of the founders of the field of positive psychology, Martin Seligman and Christopher Peterson, have published a classification of character strengths and virtues called Values in Action (VIA) that is intended to be the counterpart of the American Psychological Association's canonical Diagnostic and Statistical Manual of Mental Disorders (DSM). ${ }^{189}$ Just as the DSM identifies the psychological disorders that afflict human beings, the VIA is designed to describe and classify the "strengths and virtues that enable human thriving." 190 Seligman and Peterson argue that psychology, already armed with a vocabulary to speak about human problems, now needs a "vocabulary for speaking about the good life and assessment strategies for investigating its components."191 As such, the VIA identifies six virtues that extensive research shows are endorsed in nearly every world society: wisdom, courage, humanity, justice, temperance, and transcendence. Under each virtue, the VIA identifies particular strengths that met twelve separate criteria for inclusion. ${ }^{192}$ The following table shows Peterson and

Michigan Ross School of Business, Center for Positive Organizational Scholarship, http://www.bus.umich.edu/Positive (last visited Apr. 1, 2009); University of Pennsylvania, Authentic Happiness, http://www.authentichappiness.com (last visited Apr. 1, 2009); University of Pennsylvania, Positive Psychology Center, http:/www.positivepsychology.org (last visited Apr. 1, 2009).

187. See, e.g., Claudia Wallis, The New Science of Happiness, TIME, Jan. 17, 2005, at A2, available at $\mathrm{http} / / \mathrm{www} . \mathrm{time} . \mathrm{com} / \mathrm{time} / \mathrm{magazine} /$ article/(0,9171,1015832,00.html; see also Time, Mind \& Body Happiness, http://www.time.com/time/2005/happiness (last visited Apr. 1, 2009) (displaying additional stories from the January 17, 2005 issue of Time that explored the implications of positive psychology research).

188. Gabel \& Haidt, supra note 27, at 108.

189. See Christopher Peterson \& Martin E.P. Seligman, Character Strengths and VIRTUES: A HANDBOOK AND CLASSIFICATION (2004).

190. Seligman et al., supra note 29 , at 411.

191. Christopher Peterson, A Primer in Positive Psychology 137 (2006).

192. As described by Seligman, the criteria are 1) "ubiquity - is widely recognized across cultures," 2) "fulfilling - contributes to individual fulfillment, satisfaction, and happiness broadly construed," 3) "morally valued - is valued in its own right and not as a means to an end," 4) "does not diminish others - elevates others who witness it, producing admiration, not jealousy," 5) "nonfelicitous opposite - has obvious antonyms that are "negative," 6) "traitlike - is an individual difference with demonstrable generality and stability," 7) "measurable - has been successfully measured by researchers as an individual difference," 8) "distinctiveness - is not redundant 
Seligman's classification of these six virtues and their coordinate twenty-four character strengths:

\section{Classification of Character Strengths ${ }^{193}$}

\section{Wisdom and Knowledge}

Cognitive strengths that entail the acquisition and use of knowledge

\begin{tabular}{ll} 
Creativity & $\begin{array}{l}\text { Thinking of novel and productive ways to do things } \\
\text { Taking an interest in ongoing experience } \\
\text { Curiosity }\end{array}$ \\
Thinking things through and examining them from all \\
Open-Mindedness & $\begin{array}{l}\text { sides } \\
\text { Love of Learning }\end{array}$ \\
Perspective & Mastering new skills, topics, and bodies of knowledge \\
\hline
\end{tabular}

\section{Courage}

Emotional strengths that involve the exercise of will to accomplish goals in the face of opposition, external or internal

\begin{tabular}{ll}
\hline Authenticity & Speaking the truth and presenting oneself in a genuine \\
way & Not shrinking from threat, challenge, difficulty, or pain \\
Persistence & Finishing what one starts \\
Zest or Vitality & Approaching life with excitement and energy \\
\hline
\end{tabular}

\section{Humanity}

Interpersonal strengths that involve "tending and befriending" others

\begin{tabular}{ll}
\hline Kindness & $\begin{array}{l}\text { Doing favors and good deeds for others } \\
\text { Valuing close relations with others }\end{array}$ \\
Social Intelligence & $\begin{array}{l}\text { Being aware of the motives and feelings of self and } \\
\text { others }\end{array}$ \\
\hline
\end{tabular}

\begin{tabular}{ll}
\hline & \multicolumn{1}{c}{ Justice } \\
& Civic strengths that underlie healthy community life \\
\hline Fairness & Treating all people the same according to notions of \\
Leadership & fairness and justice \\
Citizenship & Organizing group activities and seeing that they happen \\
\hline
\end{tabular}

(conceptually or empirically) with other character strengths," 9) "paragons - is strikingly embodied in some individuals," 10) "prodigies - is precociously shown by some children or youths," 11) "selective absence - is missing altogether in some individuals," and 12) "institutions - is the deliberate targeting of societal practices and rituals to try to cultivate it." Seligman et al., supra note 29, at 411 .

193. Peterson \& Seligman, supra note 189 , at 29-30. 


\section{Temperance}

Strengths that protect against excess

\begin{tabular}{ll}
\hline Forgiveness & Forgiving those who have done wrong \\
Modesty & Letting one's accomplishments speak for themselves \\
Prudence & Being careful about one's choices; not saying or doing \\
things that might later be regretted
\end{tabular}

\section{Transcendence}

Strengths that forge connections to the larger universe and provide meaning

Appreciation of

Beauty and Excellence

Gratitude

Hope

Humor

Religiousness
Noticing and appreciating beauty, excellence, and/or skilled performance in various domains of life

Being aware of and thankful for the good things that happen

Expecting the best and working to achieve it

Liking to laugh and tease; bringing smiles to other people

Having coherent beliefs about the higher purpose and meaning of life

Interestingly, these twenty-four character strengths have been endorsed by adults surveyed around the world and "defy cultural, ethnic, and religious differences." ${ }^{194}$ Moreover, the relative distribution of strengths is similar across all fifty U.S. states and holds across gender. age, and education. ${ }^{195}$

Peterson and Seligman have developed an assessment tool, called the VIA Inventory of Strengths, that identifies which character strengths an individual most strongly exhibits and celebrates as his or her own. An individual's top, or "signature," strengths prove to be mostly stable over time, though they can change in response to significant life events ${ }^{196}$ or to concerted efforts at lifestyle change. ${ }^{197}$ While exhibiting any of the twenty-four character strengths is associated with life satisfaction, Peterson and his colleagues have found that the strengths most strongly associated with happiness are love, hope, curiosity, gratitude, and zest. ${ }^{198}$ Other findings have been equally interesting: for instance,

194. Seligman et al., supra note 29 , at 411.

195. The only strength whose distribution varies slightly across the United States is "religiousness, which is somewhat more evident in the South." Seligman et al., supra note 29, at 411.

196. Christopher Peterson \& Martin E.P. Seligman, Character Strengths Before and After September 11, 14 PSYCHOL. SCl. 381 (2003).

197. Peterson \& Seligmar. supra note 189, at 643.

198. Nansook Park, Christopher Peterson \& Martin E.P. Seligman, Strengths of Character and Well-Being, 23 J. Soc. \& Clinical Psichol. 603, 610 (2004): Christopher Peterson et al., 
"Students with the strengths of perseverance, prudence, and love earn better grades, even when ability test scores are held constant." 199 Studies at the U.S. Military Academy have shown that the strength of hope predicts who will stay in the service. ${ }^{200}$ And the strength of zest is associated with perceiving one's life work as a calling, as opposed to simply a job. ${ }^{201}$ The more researchers learn about which strengths correlate with which positive outcomes-for instance, success in law school-the more valuable it will be for people to learn about the VIA and reaffirm these strengths in their daily lives.

Also critical to the understanding of positive psychology is a focus on defining and measuring happiness, usually referred to as "subjective wellbeing." "202 Just as clinical psychologists use the Center for Epidemiological Studies Depression Scale ${ }^{203}$ and the Beck Depression Index ${ }^{204}$ to measure negative emotions and symptoms of depression, positive psychologists utilize measures such as the Satisfaction with Life Scale ${ }^{205}$ and the Steen Happiness Index ${ }^{206}$ to measure an individual's state of well-being. While differing definitions of happiness abound, it is essentially the experience of positive emotions, combined with feelings of meaning and purpose. ${ }^{207}$ Because happiness can be an unwieldy term for empirical study, Martin Seligman and his colleagues have divided happiness into three distinct and measurable components: pleasure, engagement, and meaning. ${ }^{208}$ Extensive research has confirmed that pursuing any

Strengths of Character, Orientations to Happiness, and Life Satisfaction, 2 J. POSITIVE PSYCHOL. 149,152 (2007).

199. Christopher Peterson \& Nansook Park, Character Strengths in Organizations, 27 J. Organizational BeHAV. 1149, 1151 (2006).

200. Id.

201. Id. For more on the distinction between a "calling orientation" and a "job orientation" toward work, see Amy Wrzesniewski et al., Jobs, Careers, and Callings: People's Relations to Their Work, 31 J. Res. Personality 21 (1997).

202. Happiness and subjective well-being are essentially the same thing, and we will continue to use the terms interchangeably here. The term "subjective well-being" is more common in scientific parlance because it emphasizes that happiness is inherently subjective; it is about how people think of their lives and what they consider to be important. ED DIFNER \& ROBERT BISWASDienER, HAPPINESS 4 (2008).

203. See Lenore S. Radloff, The CES-D Scale: A Self-Report Depression Scale for Research in the General Population, 1 APPLIEd PSyChOL. MEASUREMENT 385 (1977).

204. See Beck \& Burns, supra note 95.

205. Diener et al., supra note 78 , at 71

206. Seligman et al., supra note 29 , at 414.

207. SONJA LyUBOMIRSKY, THE HOW OF HAPPINESS 32 (2007).

208. Seligman and his colleagues describe these components respectively as 1) pursuing or maximizing frequent positive feelings, 2) being engaged in the activities of life, and 3) finding meaning in life or cultivating a meaningful life. Christopher Peterson, Nansook Park \& Martin E.P. Seligman, Orientations to Happiness and Life Satisfaction: The Full Life Versus the Emptr Life, 6 
of these three contributes to life satisfaction, but that the happiest people are those who experience all three together (thereby living what Peterson calls the "Full Life"). ${ }^{209}$

In measuring the happiness of individuals, positive psychologists have made a number of interesting findings. For instance, positive emotions are not just psychological effects: they also can be significant causal factors in behavioral outcomes. ${ }^{210}$ Psychologists Lyubomirsky, King, and Diener have discovered that happy workers are more productive than unhappy workers; they also perform better in managerial positions, produce higher sales, and receive better job evaluations and higher pay. ${ }^{211}$ While causation goes both ways - people can be happy because they receive higher pay-longitudinal studies have found happiness to be a significant causal factor of these positive outcomes. For instance, one study measured positive emotion in 272 employees and then followed their job performance for eighteen months. Those who were happier at the beginning went on to receive better evaluations and higher pay eighteen months later, even after controlling for other factors. ${ }^{212}$ Another study found that individuals who were happy as college freshmen went on to earn higher salaries sixteen years later, despite having no initial wealth advantage. ${ }^{213}$ Other studies that induce happiness in the laboratory and then look at subsequent performance show that children put into a good mood choose higher goals for themselves and perform better on cognitive tasks. ${ }^{214}$ In sum, happiness is not just a feeling that results from good events; it can also be an important part of why good events occur in the first place.

Psychologists have also discovered that, in addition to playing a causal role in behavioral outcomes, a preponderance of positive emotions can actually lead to greater physical well-being. One team of researchers exposed groups of happy,

\section{J. HAPPINESS STUD. 25, 25-27 (2005).}

209. Id. at 35. In their definitions of happiness, positive psychologists often refer to the Greek term "eudaimonia," which Aristotle described as the highest good. Though directly translated as "happiness," eudaimonia can be more accurately defined as "human flourishing." It conveys not just pleasurable feelings ("hedonia") but the deeper experience of living in accordance with one's virtues. So while positive psychologists recognize that pleasure is an important part of happiness, research confirms that people who pursue meaning, or goals more eudaimonic in nature, are more satisfied with life than those who pursue only pleasure. See PETERSON, supra note 191, at 78-79.

210. See, e.g., Sonja Lyubomirsky, Laura A. King \& Ed Diener, The Benefits of Frequent Positive Affect: Does Happiness Lead to Suc'e'ss?, 131 Psychol. Bull. 803, 846 (2005).

211. Id. at 822-23.

212. Barry M. Staw, Robert I. Sutton \& Lisa H. Pelled, Employee Positive Emotion and Favorable Outcomes at the Workplace, 5 ORG. SCI. 51, 61 (1994).

213. Ed Diener et al., Dispositional Affect and Job Outcomes, 59 SOC. INDICATORS RES. 229 (2002).

214. E.g., Harry L. Hom, Jr. \& Barry Arbuckle. Mood Induction Effects upon Goal Setting and Performance in Young Children, 12 MOTIVATION \& EMOTION 113, 119 (1988). 
neutral, and unhappy people to a strain of the cold virus and then kept them isolated for a week to avoid any confounding distractions. Amazingly, the happier individuals were better able to fight off the virus. They reported fewer symptoms like sneezing and congestion, and they also had fewer objective signs of illness as measured by doctors. ${ }^{215}$

Researchers have made remarkable findings on the relationship between health and happiness by examining groups of people outside of the laboratory as well. One study examined autobiographical journal entries written by Catholic nuns while they were in their early twenties. The researchers found that the nuns whose autobiographies contained evidence of more positive emotions lived longer than the nuns whose autobiographies contained more negative or neutral content. ${ }^{216}$ Indeed, $90 \%$ of the most cheerful quartile of nuns were alive at age eighty-five compared to only $34 \%$ of the least cheerful quartile. ${ }^{217}$ Another study on the health effects of happiness followed 2282 Mexican-Americans aged sixtyfive and older over the course of two years. Researchers found that those who experienced more positive emotions lived longer and suffered from less disability. "After controlling for age, income, education, weight, smoking, drinking, and disease, the researchers found that happy people were half as likely to die, and half as likely to become disabled."218 Positive emotions do not just improve the quality of life, they can expand the length of it as well.

While the first two foundations of positive psychology-positive character traits and positive emotions-have spawned thousands of research studies over the years, the third foundation-positive institutions - has so far garnered less empirical attention. Here, even positive psychology's advocates acknowledge that the work has barely begun. ${ }^{219}$ This third foundation is premised on the idea

215. Sheldon Cohen et al., Emotional Style and Susceptibility to the Common Cold, 65 Psychosomatic Med. 652, 655 (2003).

216. Deborah D. Danner, David A. Snowdon \& Wallace V. Friesen, Positive Emotions in Early Life and Longevity: Findings from the Nun Study, 80 J. PersonAlity \& SOC. PSYchol. 804. 808-09 (2001).

217. Seligman, supra note 1, at 4. The longitudinal nature of this study helps answer the question about causation that so often arises in correlational studies: the fact that the nuns' emotional expression at age twenty-two predicted their physical health six decades years later suggests that positive emotions are the causal factor in this relationship and makes a strong case against health as the causal factor. Indeed, after years of medical research on the physical effects of negative emotions like stress and anger, coupled with these more recent studies on positive emotions, most doctors and psychologists now accept, as the authors of the Nun Study explain. "the knowledge that there are universal, patterned emotional responses that affect physiology in way's that are potentially damaging or beneficial." Danner et al., supra note 216 , at 804 .

218. Seligman, supra note 1, at 40. A preponderance of similar studies has led Seligman to conclude that there is now an "unambiguous picture of happiness as a prolonger of life and improver of health." Id.

219. Gable \& Haidt, supra note 27, at 108. 
that there are certain institutions, communities, and groups that foster human flourishing. ${ }^{220}$ Just as emotions can be negative, neutral, or positive, so can families, churches, businesses, and national governments. What are the components of positive institutions, and what are the mechanisms behind their success? How do certain companies get the very best out of their employees, and why do some schools have happier students than others? Researchers are only beginning to answer these questions. One of the purposes of this Article is to explore further what a law school can do to become a positive institution-one that not only educates its students but also makes an active effort to preserve, if not actively improve, its students' personal well-being.

Thus far, we have discussed how positive psychology investigates and explains well-being. The next question is whether or not a person's level of wellbeing can be meaningfully improved and how that change can come about. Fortunately, decades of research on the inheritance of happiness have revealed a general consensus among psychologists that while $50 \%$ of our happiness is genetically predetermined and $10 \%$ is based on external circumstances, up to $40 \%$ is within our control and can be altered through intentional activities. ${ }^{221}$ Positive psychologists encourage individuals to take advantage of this discovery by participating in exercises, or "interventions," that are designed to increase happiness and decrease depressive symptoms. Two simple, but empirically welltested, examples will serve to illustrate.

Exercise Number 1: Using Signature Strengths in a New Way. Signature strengths are those character strengths from the VIA that are most strongly present in a particular individual. Psychologists have created a survey instrument to help individuals identify their top five strengths. ${ }^{222}$ As tested by Seligman et

\section{SeligiMan. supra note 1, at xiii.}

221. See Sonja Lyubomirsky, Kennon M. Sheldon \& David Schkade, Pursuing Happiness: The Architecture of Sustainable Change, 9 REV. GEN. PSYCHOL. 111, 116 (2005). Evidence for an inherited happiness "set-point" can be found in Lykken and Tellgen's 1996 study on identical twins. The authors concluded that because of the strong genetic influence on happiness (their research put it at nearly $80 \%$ ), "trying to be happer is as futile as trying to be taller." David Lykken \& Auke Tellegen, Happiness Is a Stochastic Phenomenon, 7 PsychOL. SCI. 186, 189 (1996). however, enough opposing research emerged over subsequent years that in 2000 Lykken officially retracted that statement and allowed that individuals can in fact change their level of happiness.

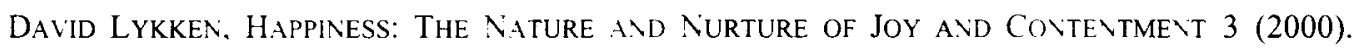
Common scientific opinion today holds that an individual's level of happiness is represented by the following equation: Happiness $=$ genetic set-point $(50 \%)+$ life circumstances $(10 \%)+$ volitional activity (40\%). See, e.g. LYLBOMIRSKY, supra note 207, at 20-22: Lyubomirsky et al., supra, at 116.

222. Se' University of Pennsylvania Authentic Happiness, Authentic Happiness Research Projects Seeking Participants, http:/www.authentichappiness.sas.upenn.edu/resources.aspx (last visited Apr. 25. 2009) (noting that the Positive Psychology Center is seeking participants for online research studies and offering the VIA Signature Strengths Questionnaire, among other assessments, 
al., this exercise requires participants to take this inventory and utilize one of their top five strengths in a new and different way every day for one week. ${ }^{223}$ In a randomized controlled study of 577 adult participants, researchers found that individuals who completed this exercise for one week were significantly happier and less depressed than those utilizing a placebo exercise. Moreover, the benefits of the intervention are enduring; they appeared at the one-month follow-up and continued for the three-month and six-month follow-ups. ${ }^{224}$

Exercise Number 2: Practicing Gratitude. This intervention requires that individuals write down a short list of things they are grateful for every day or every week. ${ }^{225}$ In the first set of studies on this exercise, a group of participants wrote down five things they were grateful for once a week for ten weeks in a row. ${ }^{226}$ At the end of the study, compared to control groups who wrote about negative or neutral topics each week, the gratitude groups were happier, more optimistic, and even reported fewer physical problems (such as headaches). ${ }^{227}$ Further studies on individuals with chronic illnesses revealed that, on days when they wrote down what they were grateful for, they experienced increased positive emotions (including feelings of joy, excitement, and pride). they felt more connected to other people, and their quality of sleep improved. ${ }^{228}$ In yet another study, participants who wrote down three good things each day for a week were happier and less depressed than the control group (who performed a placebo exercise) at the one-month, three-month, and six-month follow-ups. As with the signature strength exercise, participants were even more likely to remain happier the longer they continued the exercise. ${ }^{229}$

These examples are small but significant indications of the power of positive psychology. That such seemingly simple exercises can result in measurable and statistically significant increases in happiness and decreases in depression says much about our ability to change our own well-being through intentional activities. Interventions such as these could provide the basis for a positive psychology program for law students that could help to create a buffer against the

for individuals who register with the website).

223. Seligman et al., supra note 29 , at 415-16.

224. Id. at 418-19.

225. These items need not be profound or complicated, but they should be specific. In one of the gratitude studies that produced significant happiness benefits, typical items recorded by participants included "mom," "a healthy body," and "AOL instant messenger." LYL'BOMIRSKY, supra note 207, at 91.

226. Robert A. Emmons \& Michael E. McCullough, Counting Blessings Versus Burdens: An Experimental Investigation of Gratitude and Subjective Well-Being in Daily Life, $84 \mathrm{~J}$. PERSONALITY \& SOC. PSYCHOL. 377 (2003).

227. Id. (discussing the results of three randomized controlled trials).

228. Robert a. Emmons, Thanks! How the New Science of Gratitude Can Make yol HAPPIER 32-33 (2007).

229. Seligman et al., supra note 29, at 418-19. 
stress and depression associated with law school study.

\section{B. Using Positive Psychology To Help Improve Law Student Well-Being}

Although it is easy to describe the basic principles of positive psychology, it is considerably more difficult to develop a program to improve the lives of law students and help prevent stress and depression. Nevertheless, we have several suggestions to help administrators, faculty, and students begin to think about how they might utilize this powerful new research. All of these suggestions require the development of a proactive program of positive psychology interventions as part of an integrated plan to reach law students at the very beginning of their law school experience. The goal of the plan would be to develop in students habits and routines that will help them cope with any possible cause of stress and depression in law school, be it the stress of large-class Socratic teaching or the disappointment that $90 \%$ of the class will feel about not being in the top $10 \%$. Moreover, as the research on the benefits of happiness has borne out, a positive psychology program would not simply diminish the incidence of depression in law students' lives but also help them cultivate the positive emotions and skills necessary to foster optimal performance and improve physical well-being.

\section{Learned Optimism and the Emotional Paradox of Legal Education}

More than three decades of scientific research have revealed that optimism is one of the most powerful predictors of both happiness and depression. While optimism is typically defined as a positive expectation about the future-a belief that good things will happen ${ }^{230}$-researchers in the field focus not only on the target of people's optimism ("My exam will go well next week") but also on how they believe they will reach that target ("I have faith in my ability to perform well under pressure"). ${ }^{231}$ As it turns out, people who have these beliefs

230. Charles S. Carver \& Michael F. Scheier. Optimism, in HA`DBOOK OF Positivf. PSYCHOLOGY, supra note 182, at 231, 231.

231. See, e.g., id. at 232: C.R. Snyder, Kevin L. Rand \& David R. Sigmon, Hope Theory: A Member of the Psychology Family, in HANDBOOK OF POSITIVE PSYCHOLOGY, supra note 182, at 257, 258. Psychologists often separate the concepts of optimism, optimistic explanatory style, and hope in theoretical discussions, but they are similar enough for our purposes here that we cite research from both lines of inquiry. However, it is important to distinguish between optimism and selfesteem. As Martin Seligman notes, "self-esteem is just a meter that reads out the state of the system. It is not an end in itself. When you are doing well in school or work, when you are doing well with the people you love, when you are doing well in play, the meter will register high. When you are doing badly, it will register low." Martin E.P. SEligman, Learned OptimisM, at vi-vii (1998): cf. Roy F. Baumeister, Laura Smart \& Joseph M. Boden, Relation of Threatened Egotism to Violence and Aggression: The Dark Sule of High Silf-Esteem, 103 Psychol. Rev. 5 (1996) (presenting a fascinating study of the literature describing genocidal killers, hit men, and gang 
experience a whole host of mental, emotional, and behavioral advantages. For instance, optimists set a greater number of goals, and more difficult goals, than pessimists do, and they invest more effort in attaining these goals. ${ }^{232}$ Optimists are also more likely to stay engaged in the face of difficulty ${ }^{233}$ and persist when encountering obstacles. ${ }^{234}$ In this way, optimism is often self-fulfilling. Optimists also cope better in high stress situations ${ }^{235}$ and are able to maintain high levels of well-being during times of hardship. ${ }^{236}$ Even physical health is affected by optimism: one study found that individuals who were optimistic after undergoing coronary bypass surgery had a higher quality of life six months later. ${ }^{237}$ Another study found that optimistic thinking as a young adult accurately predicted good health thirty-five years later. ${ }^{238}$

Some of the most important optimism studies in the field of psychology have been conducted on what researchers call an individual's personal explanatory style, or "the habitual way an individual explains the causes of events." 239 Someone with an optimistic explanatory style sees negative events as local and short-lived ("It's not that bad, and it will get better"), while someone with a pessimistic explanatory style sees them as more pervasive and permanent ("It's really bad, and it's going to stay that way"). Through a series of landmark studies

leaders and arguing that it is the unwarranted high self-esteem of such persons that causes their violence).

232. See, e.g., C.R. Snyder et al., The Will and the Ways: Development and Validation of an Individual-Differences Measure of Hope, 60 J. PERSONALITY \& SOC. PSYCHOL. 570. 577-81 (1991).

233. See, e.g., Carver \& Scheier, supra note 230, at 235; Suzanne C. Segerstrom. Optimism, Goal Conflict, and Stressor-Related Immune Change, 24 J. BEHAV. MED. 441, 453 (2001).

234. See, e.g., Seligman, supra note 231, at 102; Carver \& Scheier, supra note 230, at 237.

235. See, e.g., Carver \& Scheier, supra note 230, at 235-39; Lise Solberg Nes \& Suzanne C. Segerstrom, Dispositional Optimism and Coping: A Meta-Analytic Review. 10 Persovality \& SOC. PSYCHOL. REv. 235, 244-45 (2006); Michael F. Scheier, Jagdish Kumari Weintraub \& Charles S. Carver, Coping with Stress: Divergent Strategies of Optimists and Pessimists, 51 J. Personality \& SOC. PSYCHOL. 1257, 1263 (1986).

236. See, e.g., Michael F. Scheier \& Charles S. Carver, On the Power of Positive Thinking: The Benefits of Being Optimistic, 2 CURRENT DiReCtions PSYCHOL. SCI. 26, 27 (1993).

237. Michael F. Scheier et al., Dispositional Optimism and Recovery from Coronary Arten Bypass Surgery: The Beneficial Effects on Physical and Psychological Well-Being, $57 \mathrm{~J}$. Personality \& SOC. Psychol. 1024 (1989).

238. Christopher Peterson, Martin E.P. Seligman \& George Vaillant, Pessimistic Explanaton Style Is a Risk Factor for Physical Illness: A Thirn-Five Year Longitudinal Study, 55 J. PeRsonality \& SOC. Psychol. 23 (1988).

239. Satterfield et al., supra note 21 , at 95 . As explained above. psychologists differ slightly in their conceptions of optimism, which makes optimism more of an umbrella term for these different strands of research. Explanatory style is one such strand, and for our purposes here we can use the terms optimism and optimistic explanatory style interchangeably. See supra note 231. For a detailed description of how these theories converge and diverge, see Carver \& Scheier, supra note 230 , at $232-33$. 
in the 1970s and 1980s, Martin Seligman and his fellow researchers discovered that utilizing a pessimistic explanatory style was a significant cause of depression and learned helplessness. ${ }^{240}$ Conversely, they found that using an optimistic explanatory style is an accurate predictor of happiness, resilience, high motivation, and job success. ${ }^{241}$ From insurance salesmen to collegiate athletes, individuals with an optimistic explanatory style perform better than their pessimistic counterparts and often exceed the expectations that their sheer abilities predict. ${ }^{242}$ More significantly for our purposes here, researchers have found that an optimistic explanatory style also predicts academic achievement. ${ }^{243}$ Rigorously controlled studies have shown that students who are evaluated as having an optimistic explanatory style have a higher grade point average in school, even when controlling for SAT scores and depression. ${ }^{2+4}$ This holds true even at the U.S. Military Academy: Plebes who are optimistic upon entry are not only more likely to make it through the rigors of the first year, but they also perform better academically than their SATs predict; the pessimists, in contrast, perform worse than their SATs predict and are more likely to drop out. ${ }^{245}$

The findings on optimism are particularly impressive because they are not merely correlational; Seligman and his colleagues found that they could teach individuals to be more optimistic, and in so doing, they could actively bring about these positive outcomes. ${ }^{246}$ In one such example, psychologists ran a twelve-week optimism training program for fifth and sixth graders. The children who were taught to adopt a more optimistic explanatory style reported fewer symptoms of depression than a control group, and remained less depressed for

240. Satterfield et al., supra note 21, at 95; see also Christopher Peterson \& Martin E.P. Seligman, Causal Explanations as a Risk Factor for Depression: Theory and Evidence, 91 Psychol. Riv. 347, 369 (1984); Christopher Peterson \& Lisa C. Barrett, Explanatory Style and Academic Performance Among University Freshmen, 53 J. Personality \& Soc. Psychol. 603 (1987).

241. Satterfield et al., supra note 21; see also EXPLANATORY STYLE (Gregory McClell Buchanan \& Martin E.P. Seligman eds., 1995); Susan Nolen-Hoeksema, Joan Girgus \& Martin E.P. Seligman. Learned Helplessness in Children: A Longitudinal Study of Depression, Achievement, and Explanatory Style, 51 J. Personality \& Soc. Psychol. 435 (1986); Peterson \& Barrett, supra note 240, at 603; Jason M. Satterfield \& Martin E.P. Seligman, Military Aggression and Risk Predicted by Explanatory Style, 5 PSYCHOL. SCI. 77 (1994); Scheier et al., supra note 237.

242. For the study on insurance agents at Met Life, see Martin E.P. Seligman \& Peter Schulman, Explanatory Style as a Predictor of Productivity and Quitting Among Life Insurance Agents, 50 J. Personality \& Soc. Psychol. 832 (1986). For the study on collegiate athletes, see Martin E.P. Seligman et al., Explanatory Style as a Mechanism of Disappointing Athletic Performance, I PSYCHOL. SCI. 143 (1990).

243. Satterfield et al., supra note 21, at 96.

244. Id; see SELIGMAN, supra note 231, at 150-54; Peterson \& Barrett, supra note 240, at 603.

245. SELIGMAN, supra note 231, at 152-53.

246. See, e.g., id. at 207-34. 
two years after the program ended. ${ }^{247}$ As Seligman explained,

pessimism is escapable. Pessimists can in fact learn to be optimists, and not through mindless devices like whistling a happy tune or mouthing platitudes ("Every day, in every way, I'm getting better and better"), but by learning a new set of cognitive skills. Far from being the creations of boosters or of the popular media, these skills were discovered in the laboratories and clinics of leading psychologists and psychiatrists and then rigorously validated. ${ }^{248}$

If an optimistic explanatory style can improve both subjective well-being and academic performance, and if optimism can be learned by students, this suggests a prescription for improving both the quality of life and academic performance of law students. But there is a catch, and that is what we term the emotional paradox of law school education. In all of the studies conducted by psychologists on the impact of explanatory style on academic performance, the only academic setting in which a pessimistic explanatory style has been associated with improved academic performance is law school.

In 1997, researchers published a study of students at the University of Virginia Law School in which they attempted to correlate explanatory style with law school academic success. ${ }^{249}$ Students were given the usual survey instrument to assess explanatory style at the start of their first semester of law school. The researchers obtained an exceptionally high response rate of $97 \%(n=387)^{250}$ Academic performance was measured by law school grade point average, class participation ratings, participation in legal assistance programs, moot court performance, and law journal membership. ${ }^{251}$ The researchers also gathered information on the "admissions index" (comprised of the LSAT score and undergraduate GPA) assigned by the University of Virginia Law School during the admissions process, and they used this index "to partial out the effect of prior ability on law school performance." 252 The results of the study surprised the researchers: "Explanatory style scores significantly predicted GPA paradoxically showing more pessimism related to higher achievement .... [S]tudents scoring in the pessimistic and midrange of explanatory style significantly outperformed optimistic students." 253 Explanatory style was not predictive for other success measures including moot court performance, law review membership,

247. Jane E. Gillham \& Karen J. Reivich, Prevention of Depressive' Symptoms in Schoolchildren: 4 Research Update, 10 PSYCHOL. SCI. 461 (1999).

248. SELIGMAN, supra note 231 , at 5.

249. Satterfield ct al., supra note 21.

250. Id. at 96 .

251. Id. at 97 .

252. Id.

253. Id. at 98 . 
community involvement, and classroom participation. ${ }^{254}$

So, how does one explain the results of the study? The researchers suggested that a form of prudence or an analytical approach peculiar to the law might explain the apparent paradox. They hypothesized:

Perhaps under the more rigorous demands and specific intellectual requirements of law school, diligent students who develop a sense of healthy skepticism are the highest achievers. In fact, careful attention to detail, considering all sides of an argument, seeing all potential pitfalls or catastrophes, attention to precedent rather than saltatory creativity. and thoroughness are typically seen as important traits for the successful lawyer. ${ }^{255}$

This conclusion may be supported by the link the researchers found between explanatory style and success on the LSAT. In their study, higher degrees of pessimism and non-optimism were strongly correlated with higher scores on the LSAT. Thus, the researchers speculated that "[p]erhaps optimism or nonpessimism is positively related to more general forms of academic achievement (e.g. SAT and UGPA) but is contraindicated for more quantitative, logical tasks (e.g. LSAT, law school)."256

This study poses some difficult and troubling questions for law schools. It complicates the use of positive psychology techniques for learned optimism as a solution to stress and depression in law school because it at least suggests the possibility that by teaching optimism in order to insulate against depression, we could be adversely affecting the legal analytical development of law students. Thus, it is important to examine the link between a pessimistic explanatory style and success in law school in order to determine whether a more optimistic approach could be taught without affecting the learning and development of necessary legal analytical abilities.

\section{Id.}

255. Id. at 103 .

256. Id. The researchers also looked at the other side of the equation, that pessimistic law students might be more subject to depression than would be suggested by the previous studies on explanatory style. Initially, the researchers noted that the pessimistic law students "might appear more prudent or cautious instead of helpless because other abilities or circumstances have attenuated or minimized the depressogenic effects of a pessimistic explanatory style. Perhaps talent, financial security, successful undergraduate experiences, or interpersonal skills have helped compensate for what might otherwise predispose them to depression and disempowerment." Id. at 103-04. The researchers did acknowledge that they could not rule out the possibility that law school pessimists were at a greater risk for depression since the study did not include any measures of depression, and they had no follow-up data. They concluded that only additional research would answer that question. Id. at 104. Based on the research discussed earlier in this article, it seems clear that, although we cannot directly attribute the depression to a pessimistic explanatory style, law students clearly suffer elevated levels of stress and depression. 
The Virginia study's authors could be correct that there is a connection between a pessimistic explanatory style and the analytical approach that is taught and valued in law schools, but the concept of "prudence" does not precisely capture what that connection might be. Prudence is certainly a trait that is valued in the legal profession. Indeed, as one of the study's authors noted in a later article:

Prudence enables a good lawyer to see snares and catastrophes that might conceivably occur in any given transaction. The ability to anticipate a whole range of problems that non-lawyers do not see is highly adaptive for the practicing lawyer. Indeed clients would be less effectively served if lawyers did not so behave, even though this ability to question occasionally leads to lawyers being labeled as deal breakers or obstructionists. ${ }^{257}$

Although this statement certainly seems correct with respect to lawyers, it does not apply to how most law students are graded in law school. For better or for worse, law students are not graded on the kinds of tasks that require lawyers to exercise the kind of prudence described by Seligman.

As the study authors recognize, law school testing focuses on the ability to analyze a complex fact situation in light of difficult legal principles, requiring students to assess a problem from all angles and see many perspectives ${ }^{258}$ This is different, however, from the prudence Seligman describes because it is not so much foreseeing problems that might occur in the future and planning for those problems, but rather identifying problems with legal arguments and developing a critical approach to analyzing legal issues. Law schools teach students to look for flaws in arguments, and they train them to be critical rather than accepting. This ability is a crucial skill for lawyers in practice, but, if applied to one's personal life, may have significant negative consequences. Training in critical analysis may lead students to apply the same critical approach to their own life and the problems that they encounter in personal relationships. That may lead students to overestimate the significance and permanence of the problems they encounter, which is precisely the kind of pessimistic explanatory style that leads to stress and depression.

In addition to the critical analytical style that is taught and rewarded in law school, there are other reasons why pessimistic law students may do better. The

257. Seligman et al., supra note 3 , at 56.

258. One truly disconcerting possibility, not mentioned by the study's authors, is that law professors may teach students to adopt a pessimistic explanatory style. If optimism can be learned, it stands to reason that pessimism can be learned as well. If we teach what we test on, and both the material that we teach and test rewards a pessimistic explanatory style, we may in effect be teaching our students to adopt a depressogenic perspective on life. If true, it is all the more reason to develop a program to help buffer students against stress and depression while they learn the legal analytical style in class. 
use of the Socratic method in law schools and the goal of teaching analytical skills in class rather than simply imparting information put a unique emphasis upon extensive class preparation. In a class in which the goal is primarily to impart information, the students' level of preparation has relatively little impact on the ability of the student to learn what is necessary in class. In a Socratic classroom, however, a student who is unprepared on the day's material is unlikely to learn much from the Socratic dialogue going on in class. Pessimistic law students are likely to be more worried about being called upon in a Socratic classroom and, therefore, may tend to prepare more for class than their more optimistic compatriots. That extra preparation, and the benefit it confers in acquiring the analytical methods being taught in class, may be what gives pessimistic law students an edge on the exam.

Whatever the precise nature of the link between explanatory style and law school performance, the emotional paradox of legal education may provide an opportunity for important emotional training that will benefit law students not only while they are in law school, but in their life after law school as well. It is a truism in the legal world that lawyers have a hard time turning off their legal skills when they come home from work. Most litigators have had the experience of being told that they were "deposing" their children as they asked them about their day around the dinner table. Personal disputes and interactions do not go well when carried out with lawyerly analytical precision. Law students find out quickly that their relationships with people outside of law school suffer when they identify a tort or a breach of contract in every interaction. ${ }^{259}$ The beginning of law school is the time to help budding lawyers sort out the difference between the skills that are useful in their legal career and the skills that will enhance their personal lives and improve their relationships.

In short, if academic success in law school does indeed require a more critical and pessimistic approach in the classroom, and if pessimism used outside the classroom is a leading cause of depression, then law students seem to be at a significant disadvantage when it comes to avoiding depression. Of course, these conclusions are based upon only one study at one law school. It is possible that additional studies may produce different results, so the subject is surely worthy of further empirical research. The Virginia study was sufficiently rigorous such that we should pay attention to its results. The findings make it clear that the use of optimism-building exercises as a means of warding off law student depression is not contra-indicated, but doubly necessary. Students need to learn how to separate the skills they use in their professional and private lives so that the pessimism necessary for academic success does not bleed into everything else. ${ }^{260}$

259. See lijima, supra note 15 , at 528 .

260. It is well documented that people can develop flexible optimism - the ability to be pessimistic in professional life and optimistic in private life--through training. SELIGMAN supra note 1 , at 181 . 
Optimism training would give these students a crucial set of tools to cultivate happiness outside of the classroom.

\section{The Broaden-and-Build Theory of Positive Emotions}

Barbara Fredrickson of the University of North Carolina has developed a theory about the impact of positive emotions that could be of significant help in designing a program to help law students resist stress and depression. Her approach, which she calls the "broaden-and-build theory," suggests that positive emotions are more than indicators that a person is flourishing; positive emotions can also create mental health and well-being. ${ }^{261}$ Fredrickson's theory begins with the idea that positive emotions have different characteristics and functions than negative emotions. Prior to Fredrickson's work, psychologists had developed a general theory of the development of emotions that emphasized that emotions are associated with a tendency to act in a particular way. ${ }^{262}$ Psychologists theorized that this tendency is the result of natural selection in which emotions have prompted certain actions that have a specific benefit in preserving a person's life (such as fear prompting immediate flight). ${ }^{263}$ Fredrickson argues, however, that although this model may be appropriate for negative emotions, it does not adequately account for positive emotions. ${ }^{264}$

While negative emotions narrowly focus the mind and direct the body to a very specific action, positive emotions broaden a person's possibilities for thought and action. ${ }^{265}$ For instance, Fredrickson's studies show that individuals who have been primed to feel a positive emotion (either amusement or contentment) are better able to conceive of a diverse array of immediate actions than individuals who have been primed to feel either of two negative emotions (anxiety or anger). ${ }^{266}$ Other studies have confirmed that individuals experiencing positive emotions such as enjoyment and amusement exhibit more creativity and better cognitive organization than individuals experiencing negative emotions like sadness, anger, or anxiety. ${ }^{267}$ For instance, four-year-old children who are

261. Barbara L. Fredrickson, What Good Are Positive Emotions?, 2 REY. GE\. PSYCHOL. 300, 307 (1998).

262. See, e.g., Nico H. Frijda, The Emotions (1986); Richard S. Lazarus, EMotion and ADAPTATION (1991): Robert W. Levenson, Human Emotion: a Functional l'iew', in THE NATL'RE OF EMOTION 123 (Paul Ekman \& Richard J. Davidson eds., 1994).

263. Fredrickson, supra note 261 , at 302.

264. Id. at 302-03.

265. Id. at 307 . Fredrickson lists the ten positive emotions that are typically used in this type of research: "joy, gratitude, serenity, interest, hope, pride, amusement, inspiration, awe, and love." BARBARA L. FREDRI'KSON, POSITIVITY 39 (2009).

266. Barbara L. Fredrickson \& Christine Branigan, Positive Emotions Broaden the Scope of Attention and Thought-Action Repertoires, 19 COGNITION \& EMIOTION 313 (2005).

267. For a full review, see Fredric KSON, supra note 265. 
told to think of a happy memory are better able to complete learning tasks than children who are given neutral instructions. ${ }^{268}$ Elementary school students who are told to think about something happy before taking a standardized math test outperform their peers. ${ }^{269}$ And MBA students who are primed to feel positive emotions before taking part in a business negotiation secure more concessions and close the deal more successfully than their negative and neutral counterparts. ${ }^{270}$ Because of the broadening effect of positive emotions, individuals are able to depart from habitual responses to problems and analyze complex issues to arrive at new and creative solutions. ${ }^{271}$

In one of the simplest, and yet most powerful, studies on this broadening effect of positive emotions, researchers divided a sample of forty-four expert doctors into three groups, all of whom were asked to make a difficult diagnosis. ${ }^{272}$ Before performing the diagnosis task, one group was given a gift of candy (to induce positive emotion), one was given statements to read related to humanistic medicine, and one was a control group. (It should be noted that no doctor actually ate the candy, so the results can be attributed to the positive emotion caused by receiving a gift, not from raised blood sugar.) The goal of the study was not only to see how fast they performed the diagnosis, but also how flexible they were in their thinking, because diagnosis errors often result from an inflexibility called "anchoring." 273

The results of the study were remarkable. The doctors in the positive emotion group were both more efficient with their diagnosis and showed the least "anchoring" in their thinking. Specifically, doctors in the positive emotion group gave the correct diagnosis about twice as fast and showed over $60 \%$ less anchoring (i.e., more intellectual flexibility) than the other two groups. ${ }^{274}$ This

268. John (. Masters, R. Christopher Barden \& Martin E. Ford, Affective States, Expressive Behavior, and Learning in Children, 37 J. Person Ality \& Soc. Psychol. 380, 380-90 (1979).

269. Tanis Bryan \& James Bryan, Positive Mood and Math Performance, 24 J. Learning DisabiLitif.s 490, 491-92 (1991).

270. Shirli Kopelman, Ashleigh Shelby Rosette \& Leigh Thompson, The Three Faces of Eve: Strategic Displays of Positive, Negative, and Neutral Emotions in Negotiations, 99 Organizational Behav. \& Hum. Decision Processes 81, 88-92 (2006).

271. Fredrickson, supra note 261.

272. Carlos A. Estrada, Alice M. Isen \& Mark J. Young, Positive Affect Facilitates Integration of Information and Decreases Anchoring in Reasoning Among Physicians, 72 ORganizational BeHAv. \& Hum. Decision Processes 117 (1997).

273. Id. at 119. Anchoring is the tendency to latch on to the first available data and refuse to consider subsequent data that might alter the diagnosis. When a doctor remains wedded to an original theory even in the face of new information, he runs a much higher risk of misdiagnosis. Id.

274 . Id. at $126-27$. The positive emotion group gave the correct hypothesis $20 \%$ of the way through their transcript, as opposed to $39 \%$ for the control and $36 \%$ for the statements group. The positive emotion group received an average anchoring rating of 1.5 , versus 3.9 in the control and 3.7 in the statements group. $I d$. 
study is one of many to show that an influx of positive emotion (whether induced by receiving a small gift, reading positive words, or watching a humorous video) markedly improves decision-making and cognitive flexibility. ${ }^{275}$ As the authors point out, there are some important implications: first, that "seemingly mild or small affect interventions" can induce enough positive emotion in people to create a cognitive advantage, and second, that "teaching environments that are pleasant and supportive" might lead not only to happier individuals, but also to individuals capable of greater creativity and insight. ${ }^{276}$

In addition to the broadening effect, positive emotions build a person's intellectual, emotional, and physical resilience. One way they do this is by correcting the damage caused by negative emotions, what Fredrickson terms "the undoing effect." 277 To test this theory, Fredrickson and her colleagues conducted an experiment in which participants were asked to prepare a difficult timepressured speech. The participants were told that the speech might be videotaped and evaluated by their peers. ${ }^{278}$ The subjects, when faced with this task, experienced anxiety and measurable increases in heart rate, peripheral vasoconstriction, and blood pressure. The researchers then randomly assigned the participants to view one of four different films. Two of the films were designed to provoke the positive emotions of joy and contentment, one was emotionally neutral, and the fourth was designed to induce sadness. Fredrickson's hypothesis was that the participants who viewed the films designed to induce positive emotions would experience a faster recovery from the speech-induced negative physical effects. In three separate and independent samples, the subjects who reviewed the films associated with positive emotions did in fact experience a more rapid recovery than the subjects who viewed the emotionally neutral film, and the subjects who viewed the sadness-inducing film recovered least quickly of all the participants. ${ }^{279}$ Fredrickson concluded that although the mechanisms behind the undoing effect are still unknown, positive emotions are clearly powerful enough to mediate "undoing at the cardiovascular level." ${ }^{280}$ In other

275. See Peter J.D. Carnevale \& Alice M. Isen, The Influence of Positive Affect and Visual Access on the Discovery of Integrative Solutions in Bilateral Negotiation, 37 ORGANIZATIONAL Behav. \& Hum. Decision PRocesses 1 (1986); Fredrickson \& Branigan, supra note 266: Alice M. Isen, Kimberly A. Daubman \& Gary P. Nowicki, Positive Affect Facilitates Creative Problem Solving, 52 J. Personality \& Soc. Psychol. 1122 (1987); Alice M. Isen \& Barbara Means. The Influence of Positive Affect on Decision-Making Strategy, 2 Soc. CogNition 18 (1983); G. Rowe, J.B. Hirsh \& A.K. Anderson, Positive Affect Increases the Breadth of Attentional Selection, 104 ProC. NAT'L ACAD. SCI. 383 (2007).

276. Estrada et al., supra note 272, at 132.

277. See Barbara L. Fredrickson et al., The Undoing Effect of Positive Emotions, 24 MOTIVATION \& EMOTION 237 (2000).

278. Id. at 243.

279. Id. at 245-49.

280. Barbara L. Fredrickson, The Role of Positive Emotions in Positive Psychologr: 56 AM. 
words, an influx of positive emotions not only broadens at the cognitive level but also acts to reduce stress and anxiety at the physical level.

This experiment resonates particularly powerfully in the law school context. Some law student stress and anxiety results from the prospect of having to speak and respond to questions in the large classroom context. Law students seem to experience precisely the same symptoms as the participants in Fredrickson's study from essentially the same cause (public-speaking anxiety). If positive emotions helped the subjects of Fredrickson's study to recover from the stressful event more quickly, positive emotions might accomplish a similar ameliorating effect for law students. As Fredrickson concluded, "Evidence for the undoing effect of positive emotions suggests that people might improve their psychological well-being, and perhaps also their physical health, by cultivating experiences of positive emotions at opportune moments to cope with negative emotions." "281 Positive emotions thus contribute to psychological resilience, the ability to "bounce back from stressful experiences quickly and efficiently, just as resilient metals bend but do not break." 282

Because positive emotions are durable, they build resources that long outlast the feelings themselves; this provides continuing strength to overcome future obstacles and often creates an upward spiral of positive well-being. ${ }^{283}$ Psychologists have long been familiar with the kind of downward spiral in which negative emotions and a pessimistic outlook can build on themselves and lead to depression. ${ }^{284}$ Based upon the initial research on positive emotions,

the broaden-and-build theory predicts a comparable spiral in which positive emotions and the broadened thinking they engender also influence one another reciprocally, leading to appreciable increases in emotional well-being over time. Positive emotions may trigger these upward spirals, in part by building resilience and influencing the way people cope with adversity. ${ }^{285}$

In fact, that is precisely what empirical research has revealed: an increase in positive emotions leads to enhanced coping skills, which in turn predicts more positive emotions. ${ }^{286}$ In one study, Fredrickson tested individuals on their level of positive emotion and then tracked their ability to practice "broad-minded coping," that is, their ability to see multiple solutions to a problem and to step back from an obstacle and consider it objectively. Those who experienced more

PSYCHOLOGIST 218, 222 (2001).

281. Id.

282. Id.

283. Id. at 223 .

284. See Peterson \& Seligman, supra note 240.

285. Fredrickson, supra note 280 , at 223.

286. Id. 
positive emotions at Time 1 were indeed better at broad-minded coping at Time 2 , and as their coping skills increased, so too did their positive emotions. ${ }^{287}$ These findings hold true not just in the laboratory but also in studies of people enduring national crises, like September 11, 2001, ${ }^{288}$ and in studies of people who are enduring their own personal crises, such as losing a spouse. ${ }^{289}$

The implications of this research for law schools are striking. To put it bluntly, students who spend three years in law school focused solely on work, at the expense of time spent with friends and family, recreation, personal hobbies, and other activities that might induce positive emotion, seem to be putting their personal happiness at risk, decreasing their psychological resilience, and perhaps even limiting their cognitive ability. Whatever law schools can do to limit this occurrence would therefore be a welcome reform. A comprehensive, proactive effort to insulate law students from stress and depression should include an educational component to explain the benefits of positive emotions and a programmatic component that provides opportunities for students to discover and experience those positive emotions. This may involve advisors simply urging their students not to lose sight of the people and activities that bring them joy while in law school; it may involve offering a training on how to maintain a healthy work-life balance; or it may involve more formal law school sponsored events to directly induce positive emotion - from intramural sports and movie nights to community service days and class trips. Moving from psychological theory to its application in the law school context is obviously tricky, and the process will undoubtedly be full of false starts and experimental efforts that are less than complete successes. But two facts should motivate every law school to try: 1) the magnitude of the problem is indisputable, and 2) the only way to discover how to apply this new and potentially transformative research is to imagine ways to use it and test the options.

\section{The Benefits of Strengths-Based Education}

The premise behind the strengths theory of positive psychology is that people can benefit from a focus on those qualities and actions that come naturally to them, that they enjoy doing, and that they do well. In this way, a strength can be defined as a "pre-existing capacity for a particular way of behaving, thinking, or feeling that is authentic and energising to the user, and enables optimal

287. Barbara L. Fredrickson \& Thomas Joiner, Positive Emotions Trigger Upward Spirals Toward Emotional Well-Being, 13 Psy'(HOL. SCl. 172, 173-74 (2002).

288. Barbara L. Fredrickson et al., What Good Ar' Positive Emotions in Crises?: A Prospective Study of Resilience and Emotions Following the Terrorist Attacks on the L'nited States on September 11, 2001, 84 J. Personality \& Soc. PSychol. 365, 365 (2003).

289. Anthony D. Ong et al., Psychological Resilience. Positive Emotions, and Successful Adaptation to Stress in Later Life, 91 J. PERSONALITY \& SOC. PsychOL. 730, 730 (2006). 
functioning, development, and performance." ${ }^{290}$ In fact, people who use their strengths experience higher levels of energy, ${ }^{291}$ goal attainment, ${ }^{292}$ congruence, ${ }^{293}$ and well-being. ${ }^{294}$ Working on enhancing strengths has been associated with numerous positive outcomes in the workplace, including increased employee engagement and job success. ${ }^{295}$ As mentioned above, research shows that at workplaces where employees believe they have the "opportunity to do what [they] do best," there is a significantly higher rate of loyalty and employee retention and also a much higher annual yield of employee productivity. ${ }^{296}$ We also have reason to believe this relationship is causal: workplace trainings designed to help employees identify their strengths and then use them more often have proven remarkably successful at improving productivity, ${ }^{297}$ engagement, ${ }^{298}$ and company profit ${ }^{299}$ and at lowering employee turnover. ${ }^{300}$

Identifying one's strengths and then exercising them daily has also proven to increase personal fulfillment for many people. ${ }^{301}$ Since Peterson and Seligman made their VIA strengths assessment available online, ${ }^{302}$ hundreds of thousands of people have received personalized feedback about their top five signature strengths. ${ }^{303}$ As noted in Section IV.A, Peterson and Seligman's empirical research demonstrated the long-term benefits of an intervention encouraging

290. LINLEY, supra note 38, at 9.

291. Id. at 12 .

292. Id. at 45-47.

293. Id. at 154 .

294. Id.; see also Reena Govindji \& P. Alex Linley, Strengths Use, Self-Concordance and Well-Being: Implications for Strengths Coaching and Coaching Psychologists, 2 INT'L COACHING PSYCHOL. REV. 143 (2007).

295. LinleY, supra note 38, at 151; Donald O. Clifton \& James K. Harter, Investing in Strengths, in Positive Organizational Scholarship: Foundations of a New Discipline 111, 116 (Kim S. Cameron et al. eds., 2003); Hodges \& Clifton, supra note 39, at 262-65.

296. Harter et al., supra note 40 , at 269, 273-74.

297. Connelly, supra note 41.

298. Hodges \& Clifton, supra note 39, at 262.

299. Id.

300. Brad Black, The Road to Recovery, Gallup MGMT. J., Dec. 15, 2001, http://gmj.gallup.com/content/772/Road-Recovery.aspx.

301. See, e.g., FREDRICKSON, supra note 265, at 189-91; LINLEY, supra note 38, at 154; PETERSON, supra note 191, at 159; Hodges \& Clifton, supra note 39, at 263-65; Christopher Peterson \& Nansook Park, Methodological Issues in Positive Psychology and the Assessment of Character Strengths, in HANDBOOK OF Methods in Positive Psychology, supra note 182, at 292.

302. See University of Pennsylvania Authentic Happiness, supra note 222.

303. See University of Pennsylvania Authentic Happiness, VIA-Inventory of Strengths, http://www. authentichappiness.sas.upenn.edu/AIESEC/content.aspx?id=821 (last visited Apr. 25, 2009). 
participants to utilize their signature strengths in a new way each day. ${ }^{304}$ Moreover, focusing on personal strengths has also proven successful in the field of education. A study at the University of California-Los Angeles showed that students who were given feedback about their strengths and taught to integrate them into their lives experienced significant increases in self-confidence, selfreflection, and direction. ${ }^{305}$ Another study showed that strengths-based curriculum delivered over a four-year period at a Midwestern high school resulted in students with fewer absences and higher GPAs. ${ }^{306}$ In a recent university level study, incoming freshmen were informed of their top strengths before they arrived on campus and were encouraged to reinforce these strengths throughout the year. At the end of freshman year, the students had increased levels of academic self-efficacy and life satisfaction compared to a control group. $^{307}$

Moreover, our own research suggests that there are certain signature strengths that seem to be associated with resistance to stress and depression among law students. We discuss this aspect of our research and the additional suggestions for the use and development of signature strengths below. As we will show, there is evidence to suggest that encouraging the development of certain strengths may help law students counter the negative emotions engendered by law school. ${ }^{308}$

\section{Applying Strengths Theory to Legal Education: An Empirical Study}

We conducted an empirical study of students at The George Washington University Law School to examine the use of personal strengths as a possible component of a plan to relieve law student distress. The present study builds off the foundation of strengths-based research discussed above by further testing the theory that focusing on one's strengths in daily life is associated with greater life satisfaction. This experiment applies the theory to the law student population, in the hope that it will help explain why some students manage to maintain high levels of well-being in law school despite the heightened risk for depression. Our

304. Id. at 416 .

305. Clifton \& Harter, supra note 295, at 118 (citing TOM C. RATH, ME ASI RIV(i THE IMPACT of Gallup's Strengths-Based Education Program for Students (2002)).

306. Hodges \& Clifton, supra note 39, at 260-61 (citing JAMES K. HARTER, GAgie PARK High SCHOOL ReSEARCH STUdy (1998)); see also Clifton \& Harter, supra note 295, at 118.

307. Laurie A. Schreiner, Chair and Prof., Dep't. of Doctoral Higher Educ., Azusa Pacific Univ., Positive Psychology on Campus: The Impact of Strengths-Based Interventions, Paper Presented at the International Positive Psychology Summit, Wash., D.C., Oct. 2006 (notes on file with authors); s'e also Laurie A. Schreiner \& Edward Anderson, Strengths-Based Advising: A New Lens for Higher Education, 25 NAT'L ACAD. ADVISING ASS'N J. 20, 20-27 (2005).

308. See also discussion of the "broaden-and-build theory," supra text accompanying notes 261-289. 
hypothesis is that the students who are able to use their top strengths often in their daily lives will report higher levels of happiness and lower levels of stress and depression than those students who use their top strengths less often.

We asked professors in the first-year courses to invite their students to participate in the survey and requested the president of the Student Bar Association to send an e-mail to the student body with an invitation to take an online questionnaire. Of the approximately 1500 students enrolled at this law school, 140 students elected to participate (64 men and 76 women). ${ }^{309}$ The majority of respondents were in their first year at law school $(63 \%)$, but there were also second- (16\%) and third-year $(21 \%)$ students represented in the sample. Participants' ethnicity was not recorded.

The recruitment e-mail (see Appendix A) explained that the online questionnaire was part of a study on student well-being in law school. It stated that the study was unaffiliated with the law school and that participation was voluntary and anonymous. The students who agreed to participate were asked to click on a link in the e-mail that directed them to the questionnaire, which took about fifteen minutes to complete. The study was administered at the end of March, while classes were ongoing, but near the end of the law school's second semester (classes concluded in mid-April).

\section{a. Questionnaire}

The online questionnaire (see Appendix B) began with three demographic questions asking students to identify their gender, year in law school, and GPA. Among the remaining seventy-eight questions, there were four psychological measures used for this study; the first three measures assessed the well-being of the law students along three different dimensions-life satisfaction, stress, and depression - and the fourth measure assessed the different character strengths displayed by the students and how often they used them. All four measures are commonly used self-report instruments that have been tested for reliability and validity. The specific measures are as follows:

The Satisfaction With Life Scale measures overall life satisfaction by asking respondents how strongly they agree with five statements, such as "the conditions of my life are excellent." Participants then rate their responses on a seven-point scale, from "strongly disagree" to "strongly agree." The test has been used to measure life satisfaction in populations around the world and is positively associated with other measures of subjective well-being. ${ }^{310}$

To measure stress level, students were given the ten-item Perceived Stress

309. While for some studies a $10 \%$ response rate would be low, 140 participants comprises a relatively large study in the field of psychology and was sufficient to yield statistically significant results.

310. See Diener et al., supra note 78. 
Scale (PSS-10). The PSS-10 measures the degree to which students perceive their own lives as stressful, with questions such as, "In the last month, how often have you found that you could not cope with all the things that you had to do?" Answers are rated on a five-point scale, and higher scores indicate higher levels of perceived stress. ${ }^{311}$

We measured depression with the Center for Epidemiological Studies Depression Scale (CES-D), which is a twenty-item scale that asks respondents to identify how often they have experienced certain depressive symptoms over the last week. ${ }^{312}$ Scores range from zero to sixty, with higher scores indicating increased symptomology and a score of sixteen or above indicating a high risk of clinical depression. ${ }^{313}$

To identify the subjects' signature strengths, we used a questionnaire based upon Peterson and Seligman's Character Strengths and Virtues: A Handbook and Classification, in which the authors identified twenty-four strengths of character that facilitate human flourishing. ${ }^{314}$ To identify these strengths in individuals, the authors developed a VIA Inventory of Strengths questionnaire that has been demonstrated to be valid and reliable. ${ }^{315}$ While the full VIA Inventory of Strengths uses 240 questions to identify a person's five "signature strengths," a shorter twenty-four item VIA Brief Strengths Test has been developed for more time-pressured situations, which is what we used for this study. The test consists of twenty-four questions, each corresponding to one of the twenty-four character strengths. The questions ask participants to think of their everyday life and then say how frequently they exhibited each strength when it was possible to do so. For instance, to identify a participant's strength of gratitude, the question asks: "Think of actual situations in which someone else helped or benefited you. How frequently did you show gratitude or thankfulness?" Answers are then coded on a six-point scale, from "Never/Rarely" to "Always," with the option of choosing "Not Applicable."

Finally, to measure how often participants are able to use their strengths in

311. See Sheldon Cohen, Tom Kamarck \& Robin Mermelstein. A Global Me'asure of Perceived Stress, 24 J. Health \& Soc. Behav. 385 (1983); Jonathan II. Roberti, Lisa N. Harrington \& Eric A. Storch, Further Psychometric Support for the 10-Item Version of the Perceived Stress Scale, 9 J. C. COUNSELING 135 (2006).

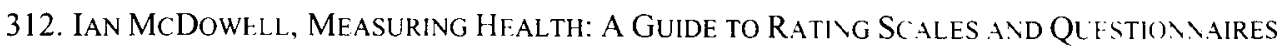
350 (2006); Radloff, supra note 203.

313. See Elizabeth A. Capezuti, Eugenia L. Sirgler \& Mathy D. Mezey. The ENCYClOPEDIA OF ELder CARE 235 (2007); LyUBOMIRSKY, supra note 207. at 36; MCDOWELl, supra note 312, at 351; Aartjan T.F. Beekman et al., Criterion V'alidity of the Center for Epidemiologic Studies Depression Scale (CES-D): Results from a Community-Based Sample of Older Subjects in the Netherlands, 27 PSYCHOL. MED. 231, 234 (1997).

314. See Peterson \& Seligman, supra note 189.

315. See Seligman et al., supra note 29. 
daily life, students were asked this final question: "Think about what you consider to be your top strengths. How often do you use your top strengths in your everyday life?" Answers were rated on a seven-point scale, ranging from one for "Never" to seven for "Always."

\section{b. Results}

The law students reported a mean stress score of $18.76(n=132 ; \mathrm{SD}=7.99)$ and a mean depression score of $19.65(n=117$; SD $=11.13){ }^{316}$ Sixty-two students $(53 \%)$ scored above a 16 on the CES-D scale, which is the threshold for a clinically significant level of depression. On the Satisfaction with Life Scale, students reported a mean score of $21.12(n=140 ; \mathrm{SD}=8.01)$. Table 1 shows a more detailed breakdown of students' life satisfaction based on their score ranges. Forty-one percent of the law students scored in the "dissatisfied" ranges of life satisfaction. Table 2 shows the mean scores on each outcome measure, broken down by class year. Third-year students showed statistically significant decreases in stress and depression, and an increase in life satisfaction, compared to first-year students.

The study confirms the hypothesis that how often students use their top strengths in daily life is strongly associated with all three dimensions of wellbeing. Pearson correlational analyses show a significant positive relationship between how often students use their strengths and their satisfaction with life ( $R$ $=0.58, p<.001$; all $p$ values two-tailed). There is also a significant negative relationship between how often they use their strengths and their scores on the stress $(R=-0.48, p<.001)$ and depression measures $(R=-0.56, p<.001)$. These results indicate that students who use their strengths on a regular basis report higher satisfaction with life and lower levels of stress and depression. Grade point average was not related to any of the three measures of well-being, nor was it related to how often students use their strengths. There was no significant gender difference in any of these correlations.

Of the twenty-four character strengths tested using the VIA Brief Strengths Test, most had no significant association with the three indicators of well-being, with six exceptions. As shown in Table 3, the strength with the highest positive correlation to well-being was zest, followed by hope, love, love of learning, good judgment, and perseverance.

The final notable result of this study is the high positive correlation between stress level and depression $(R=0.81, p<.001)$, indicating that perceived stress

316. While the total number of people who took the survey was 140 , some participants left certain questions blank. If a respondent didn't answer every question in a particular measure, we discounted them from that measure entirely. This is why each measure has a different number of respondents; for instance, 132 people completed all the questions for the stress measure, while only 117 people completed all the questions in the depression scale. 
and depressive symptoms are closely related for the law student participants.

\section{c. Discussion}

This research confirms reports from previous studies that the law student population is in significant psychological distress. T-tests confirmed that the mean stress level among study participants (18.76) was significantly higher than the general population norm (13.02), ${ }^{317}$ and that the law students' mean life satisfaction score of 21.1 was significantly lower than the 24.3 average for doctoral students $(p<.001){ }^{318}$ Most alarming, though, is that while recent studies estimate the depression rate for young adults is $11 \%,{ }^{319}$ a majority $(53 \%)$ of the law student respondents in our study met the threshold for a clinically significant level of depression. ${ }^{320}$ While previous studies have found that these high levels of distress stay constant, or even get worse, through the three years of

317. Sheldon Cohen \& Gail M. Williamson, Perceived Stress in a Probability Sample of the United States, in The Social Psychology of Health 31, 46 (Shirlynn Spacapan \& Stuart Oskamp eds., 1988).

318. William Pavot \& Ed Diener, Review of the Satisfaction with Life Scale, 5 PSYCHOL. Assessment 164, 166 (1993) (citing D.B. Allison, V.C. Alfonso \& G.M. Dunn, The Extended Satisfaction with Life Scale, 5 BEHAVIOR THERAPIST 14, 15-16 (1991).

319. Daniel Eisenberg et al., Prevalence and Correlates of Depression, Anxiety, and Suicidality Among University Students, 77 AM. J. ORTHOPSYCHIATRY 534, 537 (2007) (finding a depression rate of $11.3 \%$ among 1662 graduate students surveyed at a large Midwestern university); see also T. Aalto-Setälä et al., One-Month Prevalence of Depression and Other DSMIV Disorders Among Young Adults, 31 PSYCHOL. MED. 791, 795 (2001) (estimating the prevalence of depression to be approximately $11 \%$ among a sample drawn from Helsinki youth). Approximately $15 \%$ of people in the United States will become clinically depressed at some point during their lifetime. LyUBOMIRSKy, supra note 207, at 37 (citing Ronald C. Kessler et al., Lifetime and 12-Month Prevalence Rates of DSM-III-R Psychiatric Disorders in the United States: Results from the National Comorbidity Survey 51 ARCHIVES GE\. PSYCHIATRY 8 (1994)).

320. There are some important caveats to consider. First, the figure of $11 \%$ signifies the percentage of people who, based on questionnaires and face-to-face interviews, can be diagnosed with Major Depressive Disorder. Aalto-Setälä et al., supra note 319, at 792-93; Eisenberg et al., supra note 319 , at 535. The CES-D, on the other hand, while a valuable tool to identify groups at a high-risk for depression, "is not intended as a clinical diagnostic tool." Radloff, supra note 203, at 400. In other words, scoring above a sixteen does not guarantee an individual would be diagnosed with Major Depressive Disorder were he or she to seek clinical treatment. Second, because the CES-D is a screening tool and does not involve individual intervicws, it identifies a certain percentage of false positives-individuals whose depressive symptoms soon dissipate and would not meet the clinical criteria for depression. MCDOWELL, supra note 312, at 356. Researchers have found the CES-D false positive rate to range from $6 \%$ to $16^{\circ} \%$, depending on the study. JOHN A. Rush, Michail. B. First \& Deborah Blacker, handbook of Psychiatric Measures 506, 508 (2008). Erring on the side of caution by assuming a $20 \%$ false positive rate still leaves forty-nine students, or $42 \%$ of our study participants, with clinically significant symptoms of depression. 
law school, ${ }^{321}$ our study found that third-year students fared better on all three measures of well-being. Still, they too experienced elevated levels of distress-a third of the third-year students scored above a sixteen on the CES-D, indicating symptoms of clinical depression. Taken in conjunction with similar results from previous studies on law student depression, these findings should give law schools a reason to take action on behalf of their students.

One potential aid to the reform process may be our finding that depression and stress are so highly correlated among law students. Stress is often considered an accepted and inevitable part of law school, yet law schools have tended to ignore the problems that typically result from it. ${ }^{322}$ Our findings suggest that avoiding the consequences of stress is impossible; whether or not there is a causal link, stress and depression are inextricably connected in law school. High stress levels interfere with students' ability to process and store information ${ }^{323}$ and can lead to disengagement from tasks, ${ }^{324}$ increased aggression, ${ }^{325}$ lowered performance, ${ }^{326}$ loss of personal relationships, ${ }^{327}$ and substance abuse problems. ${ }^{328}$ Given the extremely elevated levels of alcohol and drug use among lawyers and its negative effect on the profession itself, ${ }^{329}$ it seems in the best interest of law schools to contribute to the reduction of student stress. While there are some short-term salves for student stress, including relaxation techniques and physical exercise, noticeable improvements in student well-being will require larger changes. ${ }^{330}$

Given the large numbers of law students who suffer from depression, it is all the more remarkable that some students are able to maintain healthy levels of well-being throughout law school. With the strengths-based approach of positive psychology as our foundation, we hypothesized that the students who use their top strengths more often in daily life would be the ones to report higher levels of well-being. This was indeed the case: students who find ways to use their top strengths are less likely to suffer from depression and stress and more likely to report satisfaction with life. It should be noted that our study suggests only correlation, not causation; we do not know if a focus on personal strengths can

321. See, e.g., Benjamin et al., supra note 58, at 246.

322. See Krieger, supra note 73, at 115-16.

323. Daniel Goleman. Social intelligence: The New Science of Hlian Relationships 268-74 (2006); Glesner, supra note 15, at 637.

324. Glesner, supra note 15 , at 636.

325. Id. at 638-39.

326. Id. at 637-38; Alfini \& Van Vooren, supra note 33, at 65.

327. Id. at 65.

328. Id. at 63; Glesner, supra note 15, at 640-41.

329. Allan, supra note 5; Beck et al., supra note 4.

330. Cf. Alfini \& Van Vooren, supra note 33, at 64 (arguing that relieving stress in the legal workplace will require institutional changes to work environments). 
actively improve well-being in law school, or if happier law students are simply inclined to use their strengths more often. However, taken in conjunction with previous research that shows a focus on strengths improves life satisfaction and lowers depression levels in the general population, ${ }^{331}$ we believe it is worth pursuing the theory that a strengths-based focus in law school may be able to buffer against psychological distress. Is there something specific about the law school experience that makes a focus on signature strengths particularly useful to combat the elevated risk of stress and depression? There may be.

One of the principal themes in the literature on law student distress is that students suffer from the loss of individual character. Some law students find themselves fighting a losing battle to maintain their personal code of ethics, ${ }^{332}$ their personal relationships, ${ }^{333}$ their creativity, ${ }^{334}$ their ideals, and their original career aspirations. ${ }^{335}$ In addition, the constant emphasis on linear thinking and logic can come at the expense of students' emotional selves because, as one critic notes, law school requires "a continual attempt to suppress one's emotions" and forces "the splitting and polarization of 'intellect' and 'feeling." "336 When this is combined with the singular focus on academic performance, "[1]aw school seems to communicate to students that it is how you do, rather than who you are, that really matters." ${ }^{337}$ These observations are consistent with Elizabeth Mertz's study of first-year contracts classes, discussed in Part III above, ${ }^{338}$ in which she found that the students were taught a "deceptive metapragmatic ideology" that results in "the unmooring of the self" and "a fluidity of voice and footing and position." "339

For a law student faced with these threats to individual identity, the ability to maintain the active use of signature strengths could well serve as a powerful antidote. A student who uses his top strengths every day would feel not that law school is stripping him of who he is, but that it is bringing out the very best of what he has to offer. Perhaps not coincidentally, we found that two of the character strengths with the highest positive correlations to student well-being were hope and love. Deemed strengths of transcendence and humanity in the VIA classification, ${ }^{340}$ hope and love are directly tied to the emotional side of life that can become endangered in law school. It would make sense, then, that the students who find ways to channel these strengths into their everyday lives would

331. Seligman et al., supra note 29 , at 416 .

332. ELI/ABETH MERT/, supra note 139, at 120-28.

333. Iijima, supra note 15 , at 527-28.

334. Culp, supra note 15, at 67-69.

335. Sheldon \& Krieger, Linderstanding the Vegatwe Effects, supra note 8, at 894-95.

336. Culp, supra note 15 , at $77-78$.

337. Krieger, supra note 20 , at 12.

338. Se' suprat text accompanying notes 139-140.

339. MERT/, supra note 139, at 137.

340. Peterson \& SELICiNinN, supra note 189. 
be better prepared to combat the potentially damaging effect of law school on their emotional well-being.

The character strength our study found to be most highly correlated with law student well-being was zest, also described as vitality, or a "dynamic aspect of well-being marked by the subjective experience of energy and aliveness." ${ }^{341}$ Zest can also be seen as a suitable foil for the potential loss of self, because student vitality is at risk in the law school classroom. Intense competition for grades can cause many students to become detached, docile, and helpless. One Harvard Law School student in writing about the experience of law school described fellow students as "demoralized, dispirited, and profoundly disengaged from the law school experience." 342 A Harvard Law Review editor commented on "the slow seepage of personal vibrancy which follows from single-minded devotion to legal studies. ${ }^{343}$ If these are the battles law students are fighting, it would seem that the ability to call on the strength of zest and vitality in daily interactions would be a powerful tool in the fight. Not unrelated, studies have found that out of all twenty-four character strengths, zest is the one most strongly correlated with perceiving one's life work as a calling, instead of merely a job. ${ }^{344}$ It certainly makes sense that the students who feel called to the field of law are the ones best able to push through the difficult circumstances and even thrive as they pursue their goal.

This analysis of law student distress and the possible buffers against it is one of many potential answers to the problem, and there are limitations to even the most concrete findings of our study. First, we examined students at only one law school, so further research is necessary to determine how generalizable these findings are. The fact that the students at the law school we studied have elevated depression and stress levels is consistent with previous findings at other law schools, but it is possible that the high levels of stress and depression were due, at least in part, to the time (late in the second semester) when the study was administered. Second, this study examined law students at only one point during their education, while it would potentially be more useful to track student wellbeing over the course of their three years. Third, though this study found that using strengths in daily life predicted student well-being, the mechanics of this relationship are still unknown. The answers we offer are mostly conjecture, and much more empirical research is needed on several fronts-most pressingly, on the specific causes of law student depression. Finally, our study was only correlational in nature and cannot prove a causal link between use of personal strengths and improved well-being in law school. Previous research, however,

341. Id. at 273.

342. Note, Making Docile Lawyers: An Essay on the Pacification of Law Students, 111 HaRv. L. REV. 2027, 2027 (1998).

343. With the Editors, 84 HARV. L. REV. xxi, xxi (1970).

344. Peterson \& Park, supra note 199 , at 1151. 
has been able to show causation by administering strengths interventions and empirically testing participants over time. A worthy goal for further research would be to conduct such a study in the law school setting.

\section{CONLUSION: SUGGESTIONS FOR LAW SCHOOL ACTION}

We suggest that law schools take a closer look at the idea of incorporating student strengths into the law school experience. Strengths-based development has three basic stages: identification of the strength, integration of the strength into self-perception (naming it, consciously thinking about it), and capitalization on the strength through behavior. ${ }^{345}$ It would be a small task for law schools to have their incoming students take the VIA Inventory of Strengths when they first arrive, which would at least give students knowledge of their five signature strengths and the opportunity to focus further on them should they wish. A further step for law schools would be to have advisors checking in with students to encourage (and help find ways to execute) the regular use of at least one signature strength in their class work or extracurricular activities. Such "recrafting" of daily tasks to incorporate strengths has already started to gain traction in the business world, and law schools could learn from their example. ${ }^{3 / 6}$

Ideally, law schools would eventually find ways to arrange their curriculum and academic advising process so that students could choose at least one elective class that plays to a signature strength. In Seligman's work on lawyer distress, he mentions the importance of letting young lawyers do work that caters more specifically to their strengths. ${ }^{347}$ On the law school level, this recommendation has implications for career counseling in particular:

[S]ome students have talents for litigation, for example, while others lean in the direction of less confrontational forms of practice. Some have signature strengths of valour and originality, others of social intelligence and fairness. These strengths have a real world dimension: they could be factored into the career placement function at law schools in order to provide a better fit between a first job and the talents of graduating students. ${ }^{348}$

This effort at the law school level might also go a long way in improving the

345. See Clifton \& Harter, supra note 295, at 114; Hodges \& Clifton, supra note 39, at 258.

346. See, e.g., Marcus Bul kingham, Go Put Your Strt.ngths to Work: 6 Powerful Steps To AChit.ve OUtStanding Performince 4 (2007); Fredrickson, supra note 265, at 206; LINLEy, supra note 38. at 132-37; Hodges \& Clifton, supra note 39, at 256: Peterson \& Park, supra note 199, at 1151; Amy Wrzesniewski, \& Jane F. Dutton. Crafting a Job: Revisioning Emplovees as Active (rufters of their Work, 26 ACAD. OF MGMT. REV. 179. 180 (2001): Amy Wrzesniewski, Finding Positive Meaning in W'ork, in Positive Organi/ational Scholarship: Foundations of A New Disc IPline 296, 303 (Kim S. Cameron, Jane E. Dutton \& Robert E. Quinn eds., 2003).

347. SEligman, supra note 1, at 181-82.

348. Seligman et al., supra note 3, at 65 . 
state of lawyer discontent that continues to devastate the profession. The solution to the problem may well be less about law firms trying to make their lawyers happier and more about ensuring that the right people are entering the right law firms to begin with or, more generally, that students are steering themselves toward the right careers. ${ }^{349}$

As a practical matter, how could a law school put these recommendations to work for its students? First, it may require a bit of institution building. A law school might create a Student Wellness Project as a joint venture between the law school's dean of students, the university counseling center, and the law school's career development office. A law school could then add a few days to the usual first-year orientation program. During this period these three offices could work together to administer the VIA strengths survey to every entering student and begin to counsel the new students on how to find ways to utilize their signature strengths in law school as well as in their personal lives. Later, the career development office could use the signature strengths analysis as a starting point in counseling law students about their future career options. Another strengthsrelated reform for law school administrators would be to design activities that are specifically aimed at increasing the zest and vitality of students. This is an area of study ripe with possibility - there are potentially numerous positive interventions that could enhance the personal strengths that risk depletion in the traditional law school environment.

Whatever the intervention, though, we believe it is less important which strengths students cultivate and more important that they maintain (or even increase) the use of their own signature strengths. If law school threaten students' sense of self, the strengths-based approach of positive psychology aims to do just the opposite. Education scholar Edward Anderson put this point as succinctly as possible: "This is the message of the strengths-based approach to student success: Do not try to be someone else. Strive to be the person you really are-fully and completely. This is your best avenue to achieving excellence." 350 While the state of law student distress is alarming, there is hope for improvement if we look at the problem through the lens of prevention. A strengths-based approach may be one way for law schools to protect the personal well-being of their students against the stress of the law school experience.

As we have discussed above, positive psychology offers many additional insights beyond the importance of building on one's signature strengths. Law schools should begin to experiment with programs that utilize all of this research to develop proactive programs to buffer students against law school stress. These

349. Se'e Nancy Levit \& Douglas O. Linder, Happy Law Students, Happy Lawyers. 58 SYRACUSE L. REV. 351, 370-71 (2008).

350. Edward "Chip" Anderson, What Is Strengths-Based Educatiol? 5 (2004). arailable at http://www.strengthsquest.com/Library/Documents/WhatisStrengths-Based Education.pdf. 
programs can use the concepts of positive psychology to create an environment where students not only survive, but also flourish, both personally and professionally, and lay the foundation for happy and successful legal careers. 


\section{Table 1: Satisfaction With life Scale (SWLS) Scores}

SWLS Category $^{351}$

(score range)
Percentage of students

$(n=140)$
Extremely Dissatisfied

$(5-9)$

Dissatisfied

$(10-14)$

Slightly Dissatisfied

$(15-19)$

Neutral

(20)

Slightly Satisfied

$(21-25)$

Satisfied

$(26-30)$

Extremely Satisfied

$(31-35)$
$8.6 \%$

$(n=12)$

$17.9 \%$

$(n=25)$

$14.3 \%$

$(n=20)$

$5.0 \%$

$(n=7)$

$19.3 \%$

$(n=27)$

$21.4 \%$

$(n=30)$

$13.6 \%$

$(n=19)$

351. Pavot \& Diener. supra note 318, at 165. 
Table 2: Mean Well-Being Scores by Class Year

\begin{tabular}{|c|c|c|c|}
\hline $\begin{array}{l}\text { Year in Law } \\
\text { School }\end{array}$ & Life Satisfaction & Stress & Depression \\
\hline $\begin{array}{l}\text { First } \\
(n=89)\end{array}$ & $\begin{array}{l}20.37 \\
(n=89 ; \mathrm{SD}=7.62)\end{array}$ & $\begin{array}{l}20.01 \\
(n=82 ; \mathrm{SD}=7.34)\end{array}$ & $\begin{array}{l}21.74 \\
(n=74 ; \mathrm{SD}=12.31)\end{array}$ \\
\hline $\begin{array}{l}\text { Second } \\
(n=22)\end{array}$ & $\begin{array}{l}21.00 \\
(n=22 ; \mathrm{SD}=9.35)\end{array}$ & $\begin{array}{l}18.55 \\
(n=22 ; \mathrm{SD}=9.39)\end{array}$ & $\begin{array}{l}18.63 \\
(n=19 ; \mathrm{SD}=15.00)\end{array}$ \\
\hline $\begin{array}{l}\text { Third } \\
(n=29)\end{array}$ & $\begin{array}{l}23.52^{\circ} \\
(n=29 ; \mathrm{SD}=7.91)\end{array}$ & $\begin{array}{l}15.25^{* *} \\
(n=28 ; \mathrm{SD}=7.88)\end{array}$ & $\begin{array}{l}14.00^{* * *} \\
(n=24 ; \mathrm{SD}=10.33)\end{array}$ \\
\hline $\begin{array}{l}\text { Total } \\
(n=140)\end{array}$ & $\begin{array}{l}21.12 \\
(n=140 ; \mathrm{SD}=8.01)\end{array}$ & $\begin{array}{l}18.76 \\
(n=132 ; \mathrm{SD}= \\
7.09)\end{array}$ & $\begin{array}{l}19.65 \\
(n=117: \mathrm{SD}= \\
11.13)\end{array}$ \\
\hline
\end{tabular}


Table 3: Correlations Between Character StrengthS and Measures of STUdent Well-Being*

\begin{tabular}{|c|c|c|c|}
\hline $\begin{array}{l}\text { Character Strengths } \\
(n=118)\end{array}$ & $\begin{array}{l}\text { Life Satisfaction } \\
(n=140)\end{array}$ & $\begin{array}{l}\text { Stress } \\
(n=132)\end{array}$ & $\begin{array}{l}\text { Depression } \\
(n=117)\end{array}$ \\
\hline Zest & .519 & .453 & -.505 \\
\hline Hope & .357 & -.313 & -.397 \\
\hline Love & .447 & .263 & .314 \\
\hline Love of Learning & .285 & .373 & .344 \\
\hline Good Judgment & .268 & -.284 & -.410 \\
\hline Perseverance & .226 & -.315 & -.327 \\
\hline
\end{tabular}

*All correlations significant at the 0.01 level. 


\section{APPENDIX A. RECRUITMENT E-MAIL SCRIPT}

Included in this email is a link to an online survey for a study on the well being of students in law school. The study is being conducted by Elizabeth Peterson of the University of Pennsylvania, and it has been approved by the Institutional Review Board.

The survey is unaffiliated with George Washington University and completion of the survey is voluntary. Answering the survey questions typically takes 20 minutes and is strictly anonymous. All responses are treated as confidential, and in no case will responses from individual participants be identified. Rather, all data will be pooled and published in aggregate form only:

No deception is involved in the survey, and the study involves no more than minimal risk to participants (i.e., the level of risk encountered in daily life). Participants may withdraw from taking the survey at any time during the process.

You are not likely to receive any direct benefits from taking this survey, but your cooperation may help us learn how future generations of law students can increase their levels of happiness while in law school. If you have any questions or concerns, please do not hesitate to contact Elizabeth Peterson at epeterso@sas.upenn.edu. 


\section{APPendix B. Online Questionnaire Measures}

I. Preliminary Questions

What is your gender?

What year are you in law school?

What is your law school GPA?

II. Satisfaction with Life Scale

Below are five statements that you may agree or disagree with. Read each one and choose the statement that best describes how strongly you agree or disagree.

1. In most ways, my life is close to my ideal.

2. The conditions of my life are excellent.

3. I am completely satisfied with my life.

4. So far I have gotten the most important things I want in life.

5. If I could live my life over, I would change nothing.

Note. All items endorsed on the following scale:

Strongly disagree

Disagree

Slightly disagree

Neither agree nor disagree

Slightly agree

Agree

Strongly agree 


\section{Perceived Stress Scale}

The questions in this scale ask you about your feelings and thoughts during the last month. In each case, please indicate with a check how often you felt or thought a certain way.

1. In the last month, how often have you been upset because of something that happened unexpectedly?

2. In the last month, how often have you felt that you were unable to control the important things in your life?

3. In the last month, how often have you felt nervous and "stressed"?

4. In the last month, how often have you felt confident about your ability to handle your personal problems?

5. In the last month, how often have you felt that things were going your way?

6. In the last month, how often have you found that you could not cope with all the things that you had to do?

7. In the last month, how often have you been able to control irritations in your life?

8. In the last month, how often have you felt that you were on top of things?

9. In the last month, how often have you been angered because of things that were outside of your control?

10. In the last month, how often have you felt difficulties were piling up so high that you could not overcome them?

Note. All items endorsed on the following scale:

Never

Almost never

Sometimes

Fairly often

Very often 
IV. Center for Epidemiologic Studies Depression Scale

Below is a list of the ways you might have felt or behaved. Please tell me how often you have felt this way during the past week.

1. I was bothered by things that usually don't bother me.

2. I did not feel like eating; my appetite was poor.

3. I felt that I could not shake off the blues even with help from my family or friends.

4. I felt I was just as good as other people.

5. I had trouble keeping my mind on what I was doing.

6. I felt depressed.

7. I felt that everything I did was an effort.

8. I felt hopeful about the future.

9. I thought my life had been a failure.

10. I felt fearful.

11. My sleep was restless.

12. I was happy.

13. I talked less than usual.

14. I felt lonely.

15. People were unfriendly.

16. I enjoyed life.

17. I had crying spells. 
18. I felt sad.

19. I felt that people dislike me.

20. I could not get "going."

Note. All items endorsed on the following scale:

Rarely or none of the time (less than 1 day)

Some or little of the time (1-2 days)

Occasionally or a moderate amount of time (3-4 days)

Most or all of the time (5-7 days)

\section{VIA Brief Strengths Test}

Think about how you have acted in the actual situations described below during the past month (four weeks). The questions ask about behaviors that most people find desirable, but we want you to answer only in terms of what you actually did. If you did not encounter a described situation, please mark the "not applicable" option. Read each one and then click on the dropdown list next to the statement and select your response.

1. Think of actual situations in which you had the opportunity to do something that was novel or innovative. How frequently did you show CREATIVITY or INGENUITY in these situations?

2. Think of actual situations in which you had the opportunity to explore something new or to do something different. How frequently did you show CURIOSITY or INTEREST in these situations?

3. Think of actual situations in which you had a complex and important decision to make. How frequently did you show CRITICAL THINKING, OPEN MINDEDNESS, or GOOD JUDGMENT in these situations?

4. Think of actual situations in which you had the opportunity to learn more about some topic, in or out of school. How frequently did you show LOVE OF LEARNING in these situations?

5. Think of actual situations in which you had the opportunity to offer advice to another person who needed it. How frequently did you show PERSPECTIVE or WISDOM in these situations? 
6. Think of actual situations in which you experienced fear or threat. How frequently did you show BRAVERY or COURAGE in these situations?

7. Think of actual situations in which you faced a difficult and time consuming task. How frequently did you show PERSEVERANCE, PERSISTENCE, DILIGENCE, or INDUSTRIOUSNESS in these situations?

8. Think of actual situations in which it was possible for you to present a false view of who you are or what had happened. How frequently did you show HONESTY or AUTHENTICITY in these situations?

9. Think of your everyday life. How frequently did you show ZEST or ENTHUSIASM when it was possible to do so?

10. Think of your everyday life. How frequently did you express your LOVE or ATTACHMENT to others (friends, family members) when it was possible to do so?

11. Think of your everyday life. How frequently did you show KINDNESS or GENEROSITY to others when it was possible to do so?

12. Think of actual situations in which the motives of other people needed to be understood and responded to. How frequently did you show SOCIAL INTELLIGENCE or SOCIAL SKILLS in these situations?

13. Think of actual situations in which you were a member of a group that needed your help and loyalty. How frequently did you show TEAMWORK in these situations?

14. Think of actual situations in which you had some power or influence over two or more other people. How frequently did you show FAIRNESS in these situations?

15. Think of actual situations in which you were a member of a group that needed direction. How frequently did you show LEADERSHIP in these situations?

16. Think of actual situations in which you had been hurt by someone else. How frequently did you show FORGIVENESS or MERCY in these situations? 
17. Think of your everyday life. How frequently did you show MODESTY or HUMILITY when it was possible to do so?

18. Think of actual situations in which you were tempted to do something that you might later regret. How frequently did you show PRUDENCE, DISCRETION, or CAUTION in these situations?

19. Think of actual situations in which you experienced wishes, desires, impulses, or emotions that you wished to control. How frequently did you show SELF CONTROL or SELF REGULATION in these situations?

20. Think of your everyday life. How frequently did you show APPRECIATION OF BEAUTY AND EXCELLENCE or AWE when it was possible to do so?

21. Think of actual situations in which someone else helped or benefitted you. How frequently did you show GRATITUDE or THANKFULNESS?

22. Think of actual situations in which you experienced failure or a setback. How frequently did you show HOPE or OPTIMISM in these situations?

23. Think of your everyday life. How frequently did you show PLAYFULNESS or HUMOR when it was possible to do so?

24. Think of your everyday life. How frequently did you show RELIGIOUSNESS or SPIRITUALITY when it was possible to do so?

Note. All items endorsed on the following scale:

Not Applicable

Never/Rarely

Occasionally

Half the time

Usually

Always 
VI. Using Signature Strengths in Daily Life

Think about what you consider to be your top strengths. How often do you use your top strengths in your everyday life?

Note. Question endorsed on the following scale:

Never

Rarely

Occasionally

Half the time

Usually

Almost always

Always 


\section{APPENDIX C. LAW SCHOOL, WEBSITES WITH INFORMATION ON Student Mental Health Programs or Student Affairs Offices}

1. Yale Law School, Office of Student Affairs. http://www.law.yale.edu/studentlife/OfficeofStudentAffairs.asp

2. Harvard Law School, Counseling Services, http://www.law.harvard.edu/current/student-services/student-life'campuslife/counseling-services.html

3. STANFORD LAW SCH., STUDENT HANDBOOK 2008-2009 (2008), available at http://www.law.stanford.edu/experience/studentlife/SLS_Student_Handbook.pdf

4. NYU Law, Student Affairs, http://www.law.nyu.edu/students/studentaffairs/index.htm

5. Columbia Law School, Health and Wellness Programs, http://www.law.columbia.edu/current_student/student_service Health_and_Well

6. Univ. of Chicago, The Law SCH., Stude`t HandBook 2008-2009 (2008). available at https:/www.law.uchicago.edu/files/studenthandbook08-09.pdf

7. University of Pennsylvania Law School, Student Affairs, http://www.law.upenn.edu/student

8. Berkeley Law, University of California, Boalt Hall, Other Health Services. http://www.law.berkeley.edu/1681.htm

9. UnIV. OF Mich. LAW SCH., STUdENT HANDBOOK (Aug. 2006). available at http://www.law.umich.edu/currentstudents/studentservices handbook Document s/handbook2006.pdf;

10. Duke Law, Office of Student Affairs, http:/'www.law.duke.edu students osa

11. Virginia Law, Office of Student Affairs. http://www.law.virginia.edu/html/students/studentaffairs.htm

12. Northwestern Law, Student Affairs, http://www.law.northwestern.edu/studentaffairs

13. Cornell Law School, Student Life, Law School Resources, http://www.lawschool.cornell.edu/studentlife resources.cfm

14. Georgetown Law, Center for Wellness Promotion. http://www.law.georgetown.edu wellness

15. UCLA Law, Health \& Wellness Services. http://www.law.ucla.edu home index.asp?page $=1227$

16. USC Law, Health \& Wellness, http://law .usc.edu students osa health health.cfm

17. Vanderbilt University Law School, Student Resources, http://law.vanderbilt.edu/student-resources/index.aspx 
18. The University of Texas at Austin School of Law, Student Services, http://www.utexas.edu/law/depts/sao/studentservices

19. Washington University Law, Student Counseling Services, http://aw.wustl.edu/advising/index.asp? ID =45

20. BU School of Law, J.D. Student Central, Counseling and Support, http://www.bu.edu/law/central/jd/services/counseling.html

21. University of Minnesota Law, Counseling \& Advising, http://www.law.umn.edu/current/counseling.html

22. Emory Law, The Office of Student Affairs, http:/www.law.emory.edu/currentstudents/student-affairs-general-information.html

23. The George Washington University Law School, Health, Wellness \& Support Resources, http://www.law.gwu.edu/Students/Pages/wellness.aspx

24. The University of Iowa College of Law, Health Care, http:/www.law.uiowa.edu/students/studentservices-health-services.php

25. Fordham Law School, Student Affairs, http:/law.fordham.edu/ihtml/sa2home.ihtml?id $=81$

26. University of Illinois College of Law, Campus Services, http://www.law.illinois.edu/current-students/campus-services.asp

27. Washington and Lee University School of Law, For Current Students, http:/law.wlu.edu/students

28. Boston College Law School, Counseling and Academic Support, http:/www.bc.edu/schools/law/services/deanstudents/counseling.html

29. University of Notre Dame The Law School, Support and Counseling, http:/law.nd.edu/student-life/student-services/support-and-counseling

30. University of Washington School of Law - Seattle, Counseling Resources, http://www.law.washington.edu/Students/StressCounseling.aspx

31. William \& Mary Law School, Services for Students, http://law.wm.edu/studentlife/studentservices/index.php

32. The Ohio State University Moritz College of Law, Student Services, http://moritzlaw.osu.edu/students/services.php

33. University of Wisconsin Law School, Current Students, Student Life, http://www.law.wisc.edu/current/studentlife.html

34. George Mason University School of Law, Student Services, http:/www.law.gmu.edu/students/services

35. UC Davis School of Law, On-Campus Services, Counseling Center, http://www.law.ucdavis.edu/current/on-campus-services/index.html

36. Maurer School of Law, Indiana University Bloomington, Contact Student Affairs, http://www.law.indiana.edu/students/contact.shtml 
37. Univ. Of Alabama Sch. OF LAW, Student HandBook (2008), available at http://www.law.ua.edu/students/handbook.pdf

38. University of California Hastings College of the Law, Counseling, http://www.uchastings.edu/health-services/counseling/index.html

39. University of Colorado at Boulder, Colorado Law, Student Life, http:/www.colorado.edu/law/studentlife

40. Georgia Law, Student Handbook, Law School Student Services, http://www.law.uga.edu/facstaffstu/students/handbook/stuserv.html

41. The University of Maryland School of Law, Office of Student Affairs, http://www.law.umaryland.edu/dept/osa/index.asp

42. UNC School of Law, Student Services, http://www.law.unc.edu/pastudents/experience/studentservices/default.aspx

43. WAKe Forest Univ. SCh. OF LAw, Student HandBooK 2008-2009 (2008). available at http://law.wfu.edu/studentlife/documents/handbook.2008.2009.pdf

44. BYU Law, Advisement, http://www.law2.byu.edu/advisement/index.php

45. The University of Arizona James E. Rogers College of Law, Counseling, http://www.law.arizona.edu/rss/counseling.cfm?page=program\&link=e

46. SMU Dedman School of Law, Counseling Services, http://www.law.smu.edu/Student-Services/Counseling-Services

47. American University Washington College of Law, Confidential Counseling \& Support, http://www.wcl.american.edu/studentaffairs/support.cfm

48. Tulane University Law School, Student Life, Resources for Students, http://www.law.tulane.edu/tlsstudentlife/index.aspx (follow the "Resources for Students" hyperlink on the right-hand side of the screen)

49. University of Connecticut School of Law, Guide to Student Services, http://www.law.uconn.edu/student-handbook/guide-student-services

50. University of Florida Levin College of Law, Student Affairs, http://www.law.ufl.edu/students/index.shtml

51. Arizona State University Sandra Day O'Connor College of Law. Current Students, http://www.law.asu.edu/? id $=252$

52. Benjamin N. Cardozo School of Law, Yeshiva University, Personal, http://www.cardozo.yu.edu/MemberContentDisplay.aspx?ccmd=ContentEdit\&u $\mathrm{cmd}=$ UserDisplay $\&$ userid $=10356 \&$ contentid $=4070 \&$ folderid $=322$

Benjamin N. Cardozo School of Law, Yeshiva University, FAQs, http://www.cardozo.yu.edu/MemberContentDisplay.aspx'?ccmd=ContentDisplay \&ucmd=UserDisplay\&userid $=10356 \&$ contentid $=1042$

53. Baylor Law School. Student Relations Committee, http://aw.baylor.edu/CurrentStudents/CS_studentRelationsCommittee.html 
54. Case Western Reserve University School of Law, From Our Dean of Students, http://law.case.edu/student_life/content.asp?id=111

55. Florida State University College of Law, Current Students \& Student Affairs, http:/Www.law.fsu.edu/current_students/index.html

56. University of Tennessee - Knoxville College of Law, Student Affairs and Records, http://www.law.utk.edu/administration/records.shtml

57. University of Cincinnati College of Law, Current Students: Resources, http://www.law.uc.edu/current/\#tabview=tab7

58. Pitt Law, University of Pittsburgh, Office of the Dean of Students, http://www.law.pitt.edu/students/officeofthedean

59. S.J. Quinney College of Law, The University of Utah, Barbara J. Dickey, Associate Dean for Student Affairs, http://www.law.utah.edu/profiles default.asp?PersonID=99\&name=Dickey, Barbara

60. Brooklyn Law School, Student Health, http:/www.brooklaw.edu/studenthealth

61. University of Kentucky College of Law, Student Services, http:/www.uky.edu/Law/current_students/student_services.html

62. University of Houston Law Center, Students, http://www.law.uh.edu/student

63. Chicago-Kent College of Law, Office of Student Services, http://www.kentlaw.edu/depts/stuservices

64. Temple University Beasley School of Law Counseling Services, http:/www.law.temple.edu/servlet/RetrievePage? site=TempleLaw\&page $=$ Curre nt_Counseling_Services

65. Villanova University School of Law, Student Affairs, http://www.law.villanova.edu/studentservices/studentaffairs

66. Loyola Law School - Los Angeles, On-Campus Psychological Counseling Office, http://intranet.lls.edu/studentaffairs/ocpco.html

67. Pepperdine University School of Law, Student Services, http://aw.pepperdine.edu/academics/student_handbook/lawserv.html

68. KU School of Law, The University of Kansas, Student Services, http://www.law.ku.edu/current/services/index.shtml

69. School of Law, University of Missouri, University Resources, http://www.law.missouri.edu/students/universityresources.html

70. Loyola University Chicago School of Law, Student Resources, Student Life, http://www.luc.edu/law'current/student_life_l.html

71. Rutgers School of Law, Office of Student Affairs, http://wwwcamlaw.rutgers.edu/site/studentaffairs

72. Seton Hall University School of Law, The Office of the Dean of Students, http://law.shu.edu/administration/student_services 
73. St. John's University School of Law, Office of Student Affairs, http://www.stjohns.edu/academics/graduate/law/current/sa.stj

74. University of Miami School of Law, Dean of Students, http://www.law.miami.edu/dos/index.php?op=1

75. University of New Mexico School of Law, Other Services, http://lawschool.unm.edu/students/support/health.php

All websites last visited Apr. 1, 2009. 